\title{
Origin of springtime ozone enhancements in the lower troposphere over Beijing: in situ measurements and model analysis
}

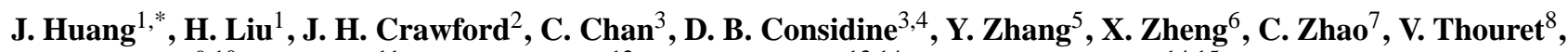

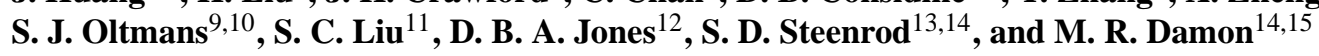 \\ ${ }^{1}$ National Institute of Aerospace, Hampton, VA, USA \\ ${ }^{2}$ NASA Langley Research Center, Hampton, VA, USA \\ ${ }^{3}$ Institute of Earth Environment, Chinese Academy of Sciences, Xi' an, China \\ ${ }^{4}$ NASA Headquarters, Washington, D.C., USA \\ ${ }^{5}$ South China Institute of Environmental Science, Guangzhou, Guangdong, China \\ ${ }^{6}$ Chinese Academy of Meteorological Sciences, Beijing, China \\ ${ }^{7}$ Department of Atmospheric Science, Peking University, Beijing, China \\ ${ }^{8}$ Laboratoire d'Aérologie, UMR5560, Toulouse, France \\ ${ }^{9}$ CIRES, University of Colorado, Boulder, CO, USA \\ ${ }^{10}$ NOAA ESRL, Boulder, CO, USA \\ ${ }^{11}$ Research Center for Environmental Changes, Academia Sinica, Taipei, Taiwan \\ ${ }^{12}$ Department of Physics, University of Toronto, Toronto, Ontario, Canada \\ ${ }^{13}$ Universities Space Research Association, Columbia, MD, USA \\ ${ }^{14}$ NASA Goddard Space Flight Center, Greenbelt, MD, USA \\ ${ }^{15}$ Science Systems and Applications Inc., Lanham, MD, USA \\ * now at: University of Washington, Seattle, WA, USA
}

Correspondence to: H. Liu (hongyu.liu-1@ nasa.gov)

Received: 15 October 2014 - Published in Atmos. Chem. Phys. Discuss.: 22 December 2014

Revised: 26 March 2015 - Accepted: 26 March 2015 - Published: 11 May 2015

\begin{abstract}
Ozone $\left(\mathrm{O}_{3}\right)$ concentrations in the lower troposphere (LT) over Beijing have significantly increased over the past 2 decades as a result of rapid industrialization in China, with important implications for regional air quality and the photochemistry of the background troposphere. We characterize the vertical distribution of lower-tropospheric $(0-6 \mathrm{~km})$ $\mathrm{O}_{3}$ over Beijing using observations from 16 ozonesonde soundings during a field campaign in April-May 2005 and MOZAIC (Measurement of Ozone and Water Vapor by Airbus In-Service Aircraft) over 13 days in the same period. We focus on the origin of $\mathrm{LT} \mathrm{O}_{3}$ enhancements observed over Beijing, particularly in May. We use a global 3-D chemistry and transport model (GEOS-Chem CTM; GEOS - Goddard Earth Observing System) driven by assimilated meteorological fields to examine the transport pathways for $\mathrm{O}_{3}$ pollution and to quantify the sources contributing to $\mathrm{O}_{3}$ and its enhancements in the springtime LT over Beijing. Out-
\end{abstract}

put from the Global Modeling Initiative (GMI) CTM is also used. High $\mathrm{O}_{3}$ concentrations (up to $94.7 \mathrm{ppbv}$ ) were frequently observed at the altitude of $\sim 1.5-2 \mathrm{~km}$. The CTMs captured the timing of the occurrences but significantly underestimated their magnitude. GEOS-Chem simulations and a case study showed that $\mathrm{O}_{3}$ produced in the Asian troposphere (especially from Asian anthropogenic pollution) made major contributions to the observed $\mathrm{O}_{3}$ enhancements. Contributions from anthropogenic pollution in the European and North American troposphere were reduced during these events, in contrast with days without $\mathrm{O}_{3}$ enhancements when contributions from Europe and North America were substantial. The $\mathrm{O}_{3}$ enhancements typically occurred under southerly wind and warmer conditions. It is suggested that an earlier onset of the Asian summer monsoon would cause more $\mathrm{O}_{3}$ enhancement events in the LT over the North China Plain in late spring and early summer. 


\section{Introduction}

Tropospheric ozone $\left(\mathrm{O}_{3}\right)$ is an effective greenhouse gas, especially in the upper troposphere (UT) (Lacis et al., 1990). It is also the primary source of hydroxyl radicals $(\mathrm{OH})$ that determine the oxidizing capacity of the atmosphere (Thompson, 1992). As an air pollutant near the surface, it has a detrimental effect on vegetation and human health. Tropospheric $\mathrm{O}_{3}$ has two sources - photochemical oxidation of hydrocarbons and carbon monoxide $(\mathrm{CO})$ by $\mathrm{OH}$ radicals in the presence of the oxides of nitrogen $\left(\mathrm{NO}_{x}=\mathrm{NO}+\mathrm{NO}_{2}\right)$, and downward transport from the stratosphere. Its precursors $\left(\mathrm{NO}_{x}\right.$, hydrocarbons, $\left.\mathrm{CO}\right)$ are generated by fossil fuel combustion, industrial processes, biomass burning, vegetation, microbial activity in soils, and lightning.

Ozone concentrations have significantly increased in the lower troposphere (LT) across China (Chan et al., 2003; Ding et al., 2008; Wang et al., 2009) over the past decades as a result of increasing anthropogenic precursor emissions (Richter et al., 2005). Elevated $\mathrm{O}_{3}$ levels not only lead to the degradation of local and regional air quality (Wang et al., 2006; Wang et al., 2008; Lin et al., 2008) but also have significant implications for the chemical environment and air quality in downwind regions (e.g., Hudman et al., 2004; Lin et al., 2012, 2014). Via deep convection or strong warm conveyor belts, Asian pollutants can be lifted up into the upper troposphere and transported to the North Pacific and North America (Jaffe et al., 1999; Liu et al., 2002, 2003; Liang et al., 2004; Cooper et al., 2010). This transpacific transport is most efficient in spring, when cold fronts frequently occur and strong westerlies prevail in the UT over eastern Asia (Liu et al., 2003; Liang et al., 2004). Note, however, that stratospheric intrusions also maximize at midlatitudes in spring. Ozonesonde measurements in western North America between 40 and $55^{\circ} \mathrm{N}$ in April-May 2006 showed that stratospheric influences can be comparable to impacts of Asian transport (Doughty et al., 2011; Moody et al., 2012). Studies of the sources and variability of $\mathrm{LT}_{3}$ over China emphasize the roles of biomass burning emissions (Liu et al., 1999; Fu et al., 2007; Lin et al., 2009), biogenic emissions (Fu et al., 2007), and the Asian monsoon system (Liu et al., 2002; Lin et al., 2009).

Located in northern China and with a population of over 19 million, Beijing is one of the world's largest cities and is facing a severe problem of $\mathrm{O}_{3}$ pollution. Ozone measurements over Beijing, derived from MOZAIC (Measurement of Ozone and Water Vapor by Airbus In-Service Aircraft) data from 1995 to 2005, showed that $\mathrm{O}_{3}$ in the LT increased by $2 \%$ annually and $\sim 4 \%$ during May-July in contrast to the flat or negative trends of other megacities at a similar latitude (Tokyo, New York, and Paris), and the measurements also exhibited higher daytime $\mathrm{O}_{3}$ concentrations than these cities (Ding et al., 2008). Wang et al. (2012) reported a summertime increase rate of $3.4 \% \mathrm{yr}^{-1}$ in the lower-tropospheric $(0$ $3 \mathrm{~km}$ ) partial $\mathrm{O}_{3}$ column over Beijing based on ozonesonde measurements from 2002 to 2012. In addition to the longterm positive trend, $\mathrm{O}_{3}$ over Beijing often experiences highconcentration episodes at ground level. Wang et al. (2006) reported that in 13 out of 39 days of surface observations at an elevated site $(280 \mathrm{~m}$ a.s.l.) in northern Beijing during June-July 2005, ambient $\mathrm{O}_{3}$ levels exceeded 120 ppbv and had a $1 \mathrm{~h}$ maximum level of $286 \mathrm{ppbv}$. The IASI (Infrared Atmospheric Sounding Interferometer) observed $\mathrm{O}_{3}$ concentrations in the LT $(3 \mathrm{~km})$ over Beijing that were up to $10 \mathrm{ppbv}$ higher than the values for the $40-50^{\circ} \mathrm{N}$ latitude band climatology, which is more representative of background $\mathrm{O}_{3}(\mathrm{Du}-$ four et al., 2010). Dufour et al. (2010) reported that the lowertropospheric partial $(0-6 \mathrm{~km})$ column $\mathrm{O}_{3}$ in Beijing shows a sharp increase in late spring, with a maximum in May.

High ground-level $\mathrm{O}_{3}$ in Beijing is caused not only by local anthropogenic emissions but also by regional and longrange transport. As reported by Streets et al. (2007), 35$60 \%$ of $\mathrm{O}_{3}$ during high- $\mathrm{O}_{3}$ episodes at Beijing Olympic Stadium originated from sources outside Beijing. Back trajectory analysis by Ding et al. (2008) indicated that elevated $\mathrm{O}_{3}$ levels in the boundary layer over Beijing during May-July were mostly related to emissions from the North China Plain. However, past investigations of the sources and transport of lower-tropospheric $\mathrm{O}_{3}$ in Beijing have mostly involved categorizing wind directions or calculating back trajectories, techniques that do not allow its various sources to be quantified. In addition, previous studies were mainly based on surface measurements, which are not adequate for a full understanding of the processes that control the vertical distribution and variability of lower-tropospheric $\mathrm{O}_{3}$ in Beijing.

To characterize the distribution and variability and quantify the sources of springtime lower-tropospheric $\mathrm{O}_{3}$ in Beijing, we analyze $\mathrm{O}_{3}$ vertical profiles measured during an ozonesonde sounding campaign, as well as aircraft measurements made by the MOZAIC program. We show that $\mathrm{O}_{3}$ enhancements in the LT over Beijing were frequently observed by ozonesondes during April-May 2005. Such $\mathrm{O}_{3}$ enhancements during some of those days were also captured by the MOZAIC aircraft. We apply the GEOS-Chem chemistry and transport model (CTM), driven by assimilated winds, to quantify the sources contributing to these $\mathrm{O}_{3}$ enhancements over Beijing and examine the corresponding pollution transport pathways in eastern China. By tagging $\mathrm{O}_{3}$ originating in different source regions and conducting sensitivity simulations, we show that these $\mathrm{O}_{3}$ enhancements were mainly due to Asian anthropogenic pollution, while the impact of the European and North American emissions were significantly smaller. We find that the high- $\mathrm{O}_{3}$ episodes occurred mostly under southerly wind conditions. We also evaluate the Global Modeling Initiative (GMI) CTM simulations with observations and show that current global models significantly underestimated the magnitude of these $\mathrm{O}_{3}$ enhancements.

This paper is structured as follows. The ozonesonde and aircraft measurements, as well as GEOS-Chem and GMI CTMs, are briefly described in Sect. 2. We describe the 
characteristics of the distribution and variability of springtime lower-tropospheric $\mathrm{O}_{3}$ in Beijing from ozonesonde observations and MOZAIC aircraft measurements in Sect. 3. The model performance in reproducing the observed characteristics is examined in Sect. 4. The model analysis and case study of various sources of lower-tropospheric $\mathrm{O}_{3}$ enhancements are presented in Sect. 5, followed by a summary and conclusions in Sect. 6.

\section{Data and methods}

\subsection{Ozonesonde and aircraft measurements}

We use two sets of in situ $\mathrm{O}_{3}$ vertical profiles over Beijing obtained during April-May 2005: one from the Transport of Air Pollutants and Tropospheric Ozone over China (TAPTO-China) (Chan et al., 2007; Zhang et al., 2012) ozonesonde campaign and the other from the MOZAIC program (Marenco et al., 1998). The concurrent availability of these two data sets allows cross validation of such measurements.

TAPTO-China was an intensive ozonesonde sounding campaign over China, conducted at five locations across southern China in the spring of 2004 (Zhang et al., 2012) and four locations across northern China in the spring of 2005. The main objective of TAPTO-China was to investigate the mechanisms controlling the spatiotemporal distribution, variability, and sources of springtime tropospheric $\mathrm{O}_{3}$ over China and its surrounding regions. Figure 1 shows the locations of the four ozonesonde stations in northern China during the second phase of TAPTO-China (AprilMay 2005): Xining $\left(36.43^{\circ} \mathrm{N}, 101.45^{\circ} \mathrm{E}\right)$, Beijing $\left(39.80^{\circ} \mathrm{N}\right.$, $\left.116.18^{\circ} \mathrm{E}\right)$, Longfengshan $\left(44.44^{\circ} \mathrm{N}, 127.36^{\circ} \mathrm{E}\right)$, and Aletai $\left(47.73^{\circ} \mathrm{N}, 88.08^{\circ} \mathrm{E}\right)$. In this study, we use the ozonesonde sounding data obtained at the Beijing station (34 m a.s.1.), which is located in the suburban Daxin district of southeastern Beijing. Sixteen ENSCI-ECC (Environmental Science Corporation electrochemical concentration cell) ozonesonde (with Vaisala RS 80 radiosonde) soundings in total were performed at this station from 11 April to 15 May 2005, with one sounding every 2-3 days on average. These sondes were launched at 13:30 local time, and the air was sampled every $15 \mathrm{~s}$. Pollution at the station is expected to be heavier than the average in the city because it is located downwind of Beijing. All raw ozonesonde data were averaged into $100 \mathrm{~m}$ vertical bins.

The MOZAIC program was initiated in 1993 to collect experimental data of $\mathrm{O}_{3}$ and water vapor obtained by five longrange commercial airlines flying all over the world. Its goal was to provide a large database for studies of atmospheric chemical and physical processes in order to improve chemistry and transport models (Marenco et al., 1998). Dual-beam UV absorption analyzers (Model 49-103 from Thermo Environment Instruments) were installed on board the aircraft to

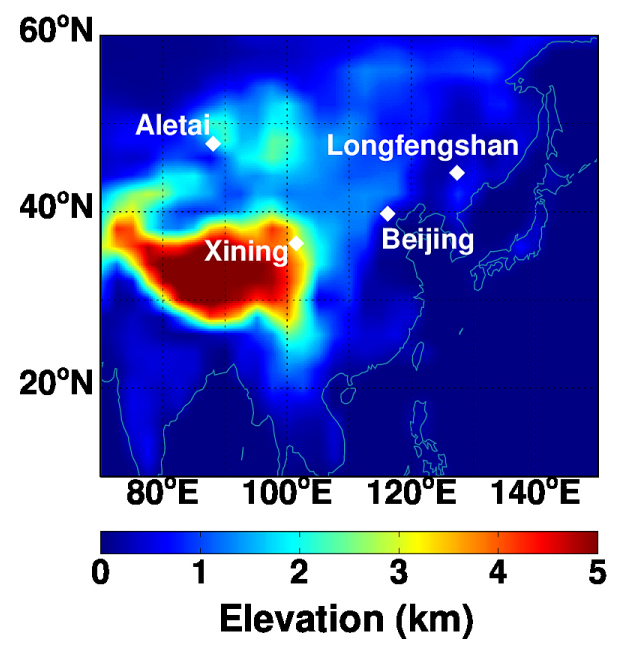

Figure 1. Locations of Beijing $\left(39.8^{\circ} \mathrm{N}, 116.18^{\circ} \mathrm{E}\right)$ and three other ozonesonde stations in north China during the second phase of the TAPTO-China campaign in April-May 2005. Colors denote surface topography.

measure $\mathrm{O}_{3}$ and were calibrated in the laboratory every 6 12 months with an overall precision of $\pm(2 \mathrm{ppbv}+2 \%$ of the measured mixing ratio) (Thouret et al., 1998, 2006). Tropospheric $\mathrm{O}_{3}$ measurements were routinely conducted during the ascents and descents of flights nearby 50 cities frequented by the MOZAIC operation (Marenco et al., 1998), including Beijing. More information about the MOZAIC program can be found on its website (http://www.iagos.fr/ web/rubrique36.html). The Beijing Capital International Airport is located about $25 \mathrm{~km}$ southeast of the urban Beijing area and is surrounded by mountains to the west, north, and northeast (Ding et al., 2008). MOZAIC obtained vertical $\mathrm{O}_{3}$ profiles in Beijing from March 1995 through March 2006. For April-May 2005, 13 profiles are available. The raw data were sampled every $4 \mathrm{~s}(\sim 30 \mathrm{~m})$ vertically and averaged into $150 \mathrm{~m}$ bins.

\subsection{CTM simulations}

GEOS-Chem is a global 3-D model of tropospheric chemistry driven by assimilated meteorological observations from the Goddard Earth Observing System (GEOS) of the NASA Global Modeling and Assimilation Office (GMAO). The use of assimilated meteorological data to drive the model makes it ideal for explaining the factors governing observed constituent distributions for a specific year. The description and evaluation of GEOS-Chem as applied to tropospheric $\mathrm{O}_{3}-$ $\mathrm{NO}_{x}$-hydrocarbon chemistry was first presented by Bey et al. (2001b), and a description of the coupled oxidant-aerosol simulation was given by Park et al. (2004). The reader is referred to the Appendix for a brief description of other aspects of the model, including the emissions used. Here, we use GEOS-Chem version v9-01-02 (http://www.geos-chem.org), 


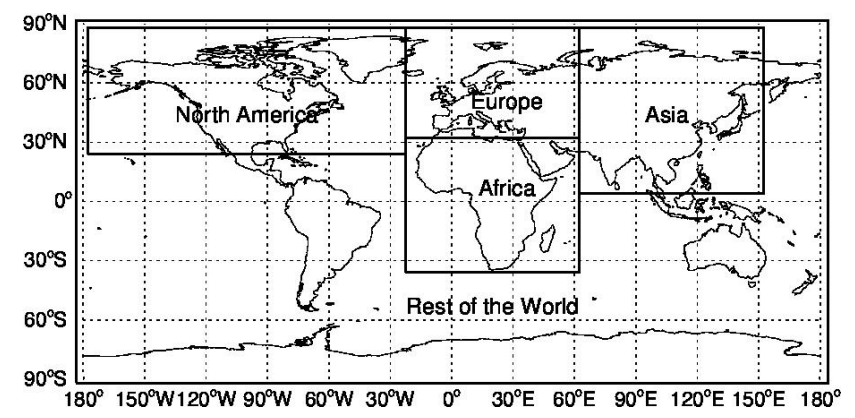

Figure 2. Tropospheric $\mathrm{O}_{3}$ source regions for tagged $\mathrm{O}_{3}$ simulations.

driven by two generations of GEOS assimilated meteorological fields - GEOS-4 (Bloom et al., 2005) and GEOS-5 (Rienecker et al., 2008) - with a degraded horizontal resolution $\left(2^{\circ} \times 2.5^{\circ}\right)$. The two sets of meteorological input data allow for an examination of the sensitivity of model results to uncertainties in our characterization of the April-May 2005 meteorology. While GEOS-Chem is the major modeling analysis tool we use, we also use outputs from simulations made with GMI CTM (http://gmi.gsfc.nasa.gov) (e.g., Strahan et al., 2007; Duncan et al., 2007; Considine et al., 2008; Allen et al., 2010) to take into account the uncertainty in model simulations. GMI CTM combines both tropospheric and stratospheric chemical mechanisms. GMI simulations are driven by the GEOS-4 and Modern-Era Retrospective analysis for Research and Applications (MERRA, i.e., GEOS-5.2.0) meteorological data sets $\left(2^{\circ} \times 2.5^{\circ}\right)$.

We use GEOS-Chem to investigate the contributions to LT $\mathrm{O}_{3}$ in Beijing from six source regions: the troposphere of Asia, Africa, Europe, North America, the stratosphere, and the rest of the world. Figure 2 shows the tropospheric $\mathrm{O}_{3}$ source regions defined in the model for tagged $\mathrm{O}_{3}$ simulations. Ozone produced in each of these source regions is transported separately in the model and removed by chemical loss and dry deposition at the same frequencies as those for total $\mathrm{O}_{3}$. The sum of all tagged $\mathrm{O}_{3}$ tracers is equivalent to the $\mathrm{O}_{3}$ concentration from the standard full-chemistry simulation (Wang et al., 1998). This approach was previously applied to a number of investigations (e.g., Liu et al., 2002; Liu et al., 2009; Zhang et al., 2012). However, it is important to note that tagged $\mathrm{O}_{3}$ by source regions does not represent the sensitivity of tropospheric $\mathrm{O}_{3}$ to emissions in those regions. This is because $\mathrm{O}_{3}$ precursors themselves can be transported out of their source regions and can therefore contribute to $\mathrm{O}_{3}$ production elsewhere.

We therefore also conduct sensitivity simulations to examine the effect of various emission types on tropospheric $\mathrm{O}_{3}$ over Beijing. In these simulations, emissions from Asian fossil fuel, biomass burning, European fossil fuel, North American fossil fuel, and lightning NO are individually shut off to quantify their contributions to $\mathrm{O}_{3}$. Simulations are conducted from August 2004 to May 2005 with the first 8 months being used for initialization.

Spring in eastern Asia is a meteorological transition season when the winter monsoon retreats and summer monsoon gradually moves northward. Figure 3 shows the average wind vectors in the LT $(\sim 870 \mathrm{hPa})$ during April-May 2005. Superimposed colors indicate the model average $\mathrm{O}_{3}$ mixing ratios. The circulation patterns and $\mathrm{O}_{3}$ distributions in the two simulations with GEOS-4 and GEOS-5 show similar features. In eastern China, the northwesterly and southwesterly winds converge around $30-40^{\circ} \mathrm{N}$ (North China Plain), flanked by the western Pacific subtropical high to the east. In this convergence zone, surface pollutants can be readily lifted out of the boundary layer and transported to the western Pacific by westerly winds in the free troposphere (Bey et al., 2001a; Liu et al., 2003). Beijing is located in the northern part of the North China Plain, where northwesterly winds prevail near the surface in spring. However, as the Siberian high weakens and the eastern Asia summer monsoon develops towards late spring, incursions of warmer tropical air from the south become more frequent and vigorous, especially in May (Ding and Chan, 2005), putting Beijing under the influence of southerly air masses.

\section{Lower-tropospheric $\mathrm{O}_{3}$ in Beijing as observed by ozonesonde and aircraft}

In this section, we examine the distribution and variability of springtime lower-tropospheric $\mathrm{O}_{3}$ in Beijing using ozonesonde and MOZAIC aircraft measurements for AprilMay 2005. Measurements were made by both platforms on 4 days: $1,3,11$, and 15 May. The vertical distributions of $\mathrm{O}_{3}$ in the LT in the two data sets are consistent on each of these 4 days. This is illustrated in Fig. 4a with the 4-day average profile. The consistency indicates that both ozonesonde and MOZAIC measurements captured tropospheric $\mathrm{O}_{3}$ concentrations over Beijing well.

Figure $4 \mathrm{~b}$ and $\mathrm{c}$ show the mean vertical distribution of $\mathrm{O}_{3}$ below $6 \mathrm{~km}$ as calculated from the April and May ozonesonde and aircraft data in comparison with model simulations. Model results will be discussed later in Sect. 4. The average $\mathrm{O}_{3}$ distribution observed in the LT over Beijing ranged from 44 to $67 \mathrm{ppbv}$, with a minimum near the surface and an enhancement at $\sim 1.5 \mathrm{~km}$. Ozone concentrations remained fairly constant ( $\sim 65 \mathrm{ppbv})$ above $\sim 1.5 \mathrm{~km}$. This LT enhancement in the vertical $\mathrm{O}_{3}$ distribution over Beijing is consistent with the MOZAIC climatology (1995-2005), where $\mathrm{O}_{3}$ concentrations peak below $2 \mathrm{~km}$ in May-July, but the peak in the latter was located at a somewhat lower altitude ( 1.0 km) (Ding et al., 2008).

The low average $\mathrm{O}_{3}$ concentration observed near the surface (below $1 \mathrm{~km}$ ) over Beijing (Fig. 4b, c) reflects the frequent low $\mathrm{O}_{3}$ concentrations below $1 \mathrm{~km}$ seen in the individual sonde or aircraft profiles (Fig. 5). The minimum LT 
GEOS-Chem, April-May

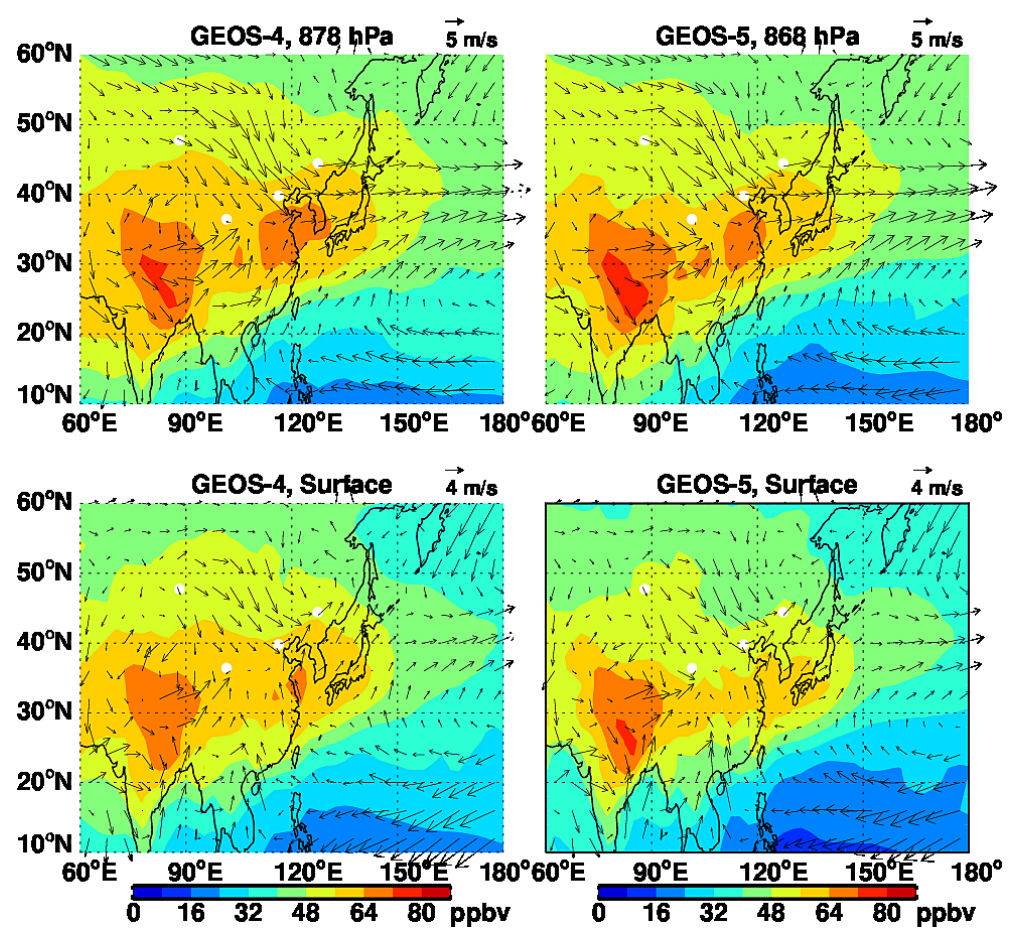

Figure 3. GEOS-4 (left panels) and GEOS-5 (right panels) horizontal wind vectors near the surface (lower panels) and $\sim 870 \mathrm{hPa}$ (upper panels) in eastern Asia during April-May 2005. Also shown as a color image are the $\mathrm{O}_{3}$ concentrations (ppbv) simulated by GEOS-Chem driven with GEOS-4 and GEOS-5 meteorological data sets. Values are averages over April-May. White dots denote the locations of four ozonesonde stations (see Fig. 1).
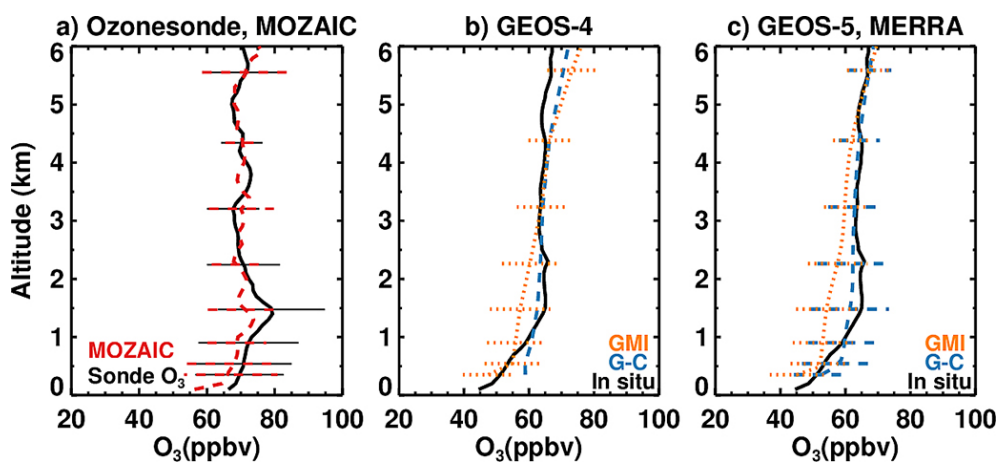

Figure 4. (a) Mean vertical profiles of $\mathrm{O}_{3}$ mixing ratios (ppbv) over Beijing averaged over 4 days (1, 3, 11, and 15 May), when both ozonesonde (black solid line) and MOZAIC aircraft (red dashed line) measurements were conducted. (b) Mean vertical profiles of $\mathrm{O}_{3}$ mixing ratios observed by ozonesonde and MOZAIC aircraft during April-May 2005 (solid black line), compared to GEOS-Chem (blue dashed line) and GMI (orange dotted line) simulations driven by the GEOS-4 meteorological fields. Daily model output was sampled at the time and location of ozonesonde and aircraft measurements. (c) Same as (b), except that GEOS-Chem and GMI were driven by the GEOS-5 and MERRA meteorological fields, respectively.

$\mathrm{O}_{3}$ concentration seen in the ozonesonde observations was a value of $0.2 \mathrm{ppbv}$ at $0.3 \mathrm{~km}$ on 13 May; on this day, $\mathrm{O}_{3}$ mixing ratios were lower than $2 \mathrm{ppbv}$ up to $0.6 \mathrm{~km}$. Low$\mathrm{O}_{3}$ episodes were also observed near the surface on 17, 23, 29 April, and 9 May. These low $\mathrm{O}_{3}$ mixing ratios are likely due to the chemical titration by high $\mathrm{NO}_{x}$ concentrations, a common characteristic in urban areas (e.g., Chan et al., 1998). Backward trajectory calculations (not shown) suggest that cleaner air masses originating from the east may also contribute to the low $\mathrm{O}_{3}$ concentrations seen here.

The $\mathrm{O}_{3}$ concentrations $(\sim 65 \mathrm{ppbv})$ at $\sim 1.5 \mathrm{~km}$ in the average profile reflect $\mathrm{O}_{3}$ enhancements ( $>70 \mathrm{ppbv}$ ) frequently 


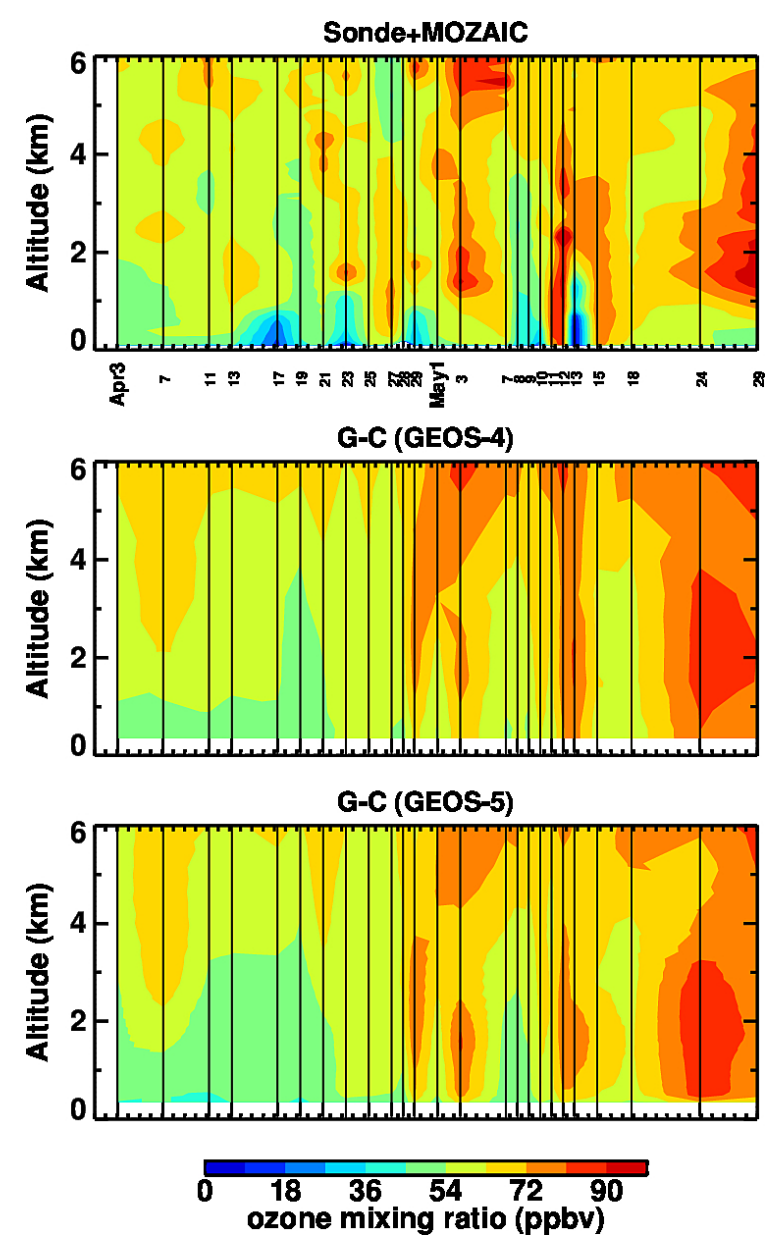

Figure 5. Time-height cross sections of lower-tropospheric $\mathrm{O}_{3}$ mixing ratios (ppbv), as observed at Beijing during April-May 2005 by ozonesonde and MOZAIC aircraft in comparison with GEOSChem simulations driven by the GEOS-4 and GEOS-5 meteorological fields. Model daily outputs are sampled in the grid box nearest to Beijing for the dates (vertical lines) of ozonesonde soundings.

observed in individual profiles during April-May 2005. Enhanced $\mathrm{O}_{3}$ mixing ratios were observed below $4 \mathrm{~km}$ in 15 out of a total of 25 days with observations: $7,13,21,23,27$, and 29 April and 1, 3, 11, 12, 13, 15,18, 24, and 29 May (Fig. 5). Of these 15 days, 11 days (i.e., all except 7 and 21 April and 1 and 13 May) saw enhanced $\mathrm{O}_{3}$ mixing ratios at $\sim 1.5 \mathrm{~km}$ over Beijing. Relatively large $\mathrm{O}_{3}$ enhancements at this altitude were mostly observed in late April and May, such as 29 April and 3, 11, 12, 15, 24, and 29 May. The maximum $\mathrm{O}_{3}$ concentrations observed in the LT were $95 \mathrm{ppbv}$ at $\sim 1.4 \mathrm{~km}$ on 3 May during the ozonesonde sounding campaign and $131 \mathrm{ppbv}$ at $\sim 2.3 \mathrm{~km}$ on 12 May as observed by MOZAIC aircraft. Ozone enhancements on 3,11, and 15 May were observed simultaneously by ozonesonde and MOZAIC aircraft.

These aforementioned springtime $\mathrm{O}_{3}$ enhancements are likely due to regional photochemical pollution. Recent studies indicate that the transport of pollutants from surrounding regions has an important influence on air quality in Beijing during spring (Zhang et al., 2006; An et al., 2007). A regional model simulation of an air pollution episode in Beijing during 3-7 April 2005 by An et al. (2007) showed that nonBeijing sources contributed about $39 \%$ to $\mathrm{PM}_{2.5}$ and $60 \%$ to $\mathrm{PM}_{10}$ concentrations in Beijing. Lin et al. (2008) showed that the North China Plain contributed 19.2 ppbv to the surface $\mathrm{O}_{3}$ at a rural site north of Beijing (Shangdianzi, one of the regional Global Atmosphere Watch stations in China) in spring. Nevertheless, intercontinental transport may also contribute to these $\mathrm{O}_{3}$ enhancements. We will address this issue in Sect. 5.

These springtime $\mathrm{O}_{3}$ enhancements over Beijing are also likely related to favorable meteorological conditions. LT temperature inversions were observed in sonde profiles over Beijing on 11, 23, 27, and 29 April and 1, 3, 9, 13, and 15 May (not shown). Specifically, strong inversions were found at $\sim 1.5 \mathrm{~km}$ on 29 April and 3 May, when relatively large $\mathrm{O}_{3}$ enhancements were seen at the same altitude. When such inversions are present, vertical mixing is suppressed, trapping $\mathrm{O}_{3}$ and its precursors below the inversion. This is similar to the elevated levels of $\mathrm{O}_{3}$ previously seen above the base of temperature inversions in and nearby the similarly polluted Los Angeles Basin (Lea, 1968; Edinger, 1973; Blumenthal et al., 1978).

The LT over Beijing is near the boundary between regions of southwesterly (southerly) and northwesterly winds during spring (Fig. 3). The transition from winter to summer monsoon during this period has an important impact on the transport of $\mathrm{O}_{3}$ in the LT. Trajectory classifications over Beijing during May-July, as shown by Ding et al. (2008), revealed that the $\mathrm{O}_{3}$ concentrations in the air masses from the south are 10-15 ppbv higher than those from the north below $2 \mathrm{~km}$, and the difference was largest at $1 \mathrm{~km}$. By comparing surface $\mathrm{O}_{3}$ concentrations observed at Shangdianzi under southwesterly (SW) and northeasterly (NE) wind conditions, Lin et al. (2008) showed that the average $\mathrm{O}_{3}$ concentrations corresponding to the $\mathrm{SW}$ wind directions were higher than those of NE wind directions in spring, and the difference was over $20 \mathrm{ppbv}$ in May. We will illustrate such influences of meteorological conditions on $\mathrm{LT} \mathrm{O}_{3}$ with a case study to be presented in Sect. 5.

\section{Model simulations of lower-tropospheric $\mathrm{O}_{3}$ over Beijing}

In this section, we present model simulations of $\mathrm{LT} \mathrm{O}_{3}$ over Beijing in comparison with in situ (ozonesonde and aircraft) measurements. Because the elevation of Beijing in the model is $290 \mathrm{~m}$ a.s.l., which is higher than the actual elevation ( $160 \mathrm{~m}$ a.s.1.), there is a small gap below $290 \mathrm{~m}$ where $\mathrm{O}_{3}$ is not simulated. Figure $4 \mathrm{~b}$, c shows the model-observation comparison of the average vertical distribution of $\mathrm{O}_{3}$ in the LT during April-May 2005. Results from both GEOS-Chem 
(driven by the GEOS-4 and GEOS-5 meteorological fields) and GMI (driven by the GEOS-4 and MERRA meteorological fields) models are shown. Figure 5 shows the time-height cross sections of the $\mathrm{LT}_{3}$ mixing ratios (ppbv), as observed by ozonesonde and aircraft and simulated by GEOS-Chem during this period.

The simulated mean vertical distributions of $\mathrm{O}_{3}$ are similar to the observations (Fig. 4b, c). The GEOS-Chem/GEOS-4 model agrees with the observations near $3-4.5 \mathrm{~km}$ but underestimates the observations by $2 \mathrm{ppbv}$ between $\sim 1$ and $2.5 \mathrm{~km}$ and overestimates $\mathrm{O}_{3}$ by 1.7-7.7 ppbv below $1 \mathrm{~km}$ and by $1.3-6.7 \mathrm{ppbv}$ above $4.5 \mathrm{~km}$, with a large bias of $\sim 8 \mathrm{ppbv}$ near the surface (Fig. 4b). The GEOS-Chem/GEOS-5 simulated $\mathrm{O}_{3}$ is in good agreement with observation above $2.5 \mathrm{~km}$ but too low by up to $6 \mathrm{ppbv}$ at $\sim 1-1.5 \mathrm{~km}$ compared to observations (Fig. 4c). Both simulations showed negative biases around $1.5 \mathrm{~km}$, with the GEOS-Chem/GEOS-4 values in slightly better agreement. Both simulations fail to reproduce the magnitude of the daily $\mathrm{LT} \mathrm{O}_{3}$ enhancements over Beijing, as discussed further below.

The GMI model simulations driven by GEOS-4 and MERRA meteorological fields (Fig. 4b, c) reproduced the observed values at $\sim 0.5 \mathrm{~km}$ better than GEOS-Chem. Above $\sim 2.5 \mathrm{~km}$, the GMI and GEOS-Chem simulations driven by the GEOS-4 meteorology are consistent. Near $1.5 \mathrm{~km}$, however, GMI/GEOS-4 has a larger negative bias than GEOSChem (Fig. 4b). The GMI/MERRA model consistently underestimates $\mathrm{O}_{3}$ observations below $4.5 \mathrm{~km}$, with the largest bias near $1.5 \mathrm{~km}(\sim 10 \mathrm{ppbv})$ and larger biases than those of GEOS-Chem/GEOS-5 (Fig. 4c).

Both GEOS-Chem/GEOS-4 and GEOS-Chem/GEOS-5 simulations capture the large-scale temporal (day-to-day) variability in the vertical distribution of $\mathrm{O}_{3}$ seen in the ozonesonde and aircraft measurements (Fig. 5). They simulate the $\mathrm{O}_{3}$ enhancement event at $\sim 1.5 \mathrm{~km}$ on 3 May well, which is the largest observed by both ozonesonde and MOZAIC aircraft at this altitude during this period. The timing of $\mathrm{O}_{3}$ enhancements, especially those observed in late April and May, is captured reasonably well. However, the model is missing the 23 April enhancement and the 27 April event is shifted to 29 April in the model. Overall, the model underestimates the magnitude of those $\mathrm{O}_{3}$ enhancements. Also, both simulations fail to reproduce the observed low$\mathrm{O}_{3}$ episodes near the surface, where the $\mathrm{O}_{3}$ concentrations are largely overestimated. Model simulations at higher horizontal resolutions that resolve the chemical titration of $\mathrm{O}_{3}$ by excessive $\mathrm{NO}_{x}$ better may help address this discrepancy.

The distribution and variability of model relative humidity (RH) are generally similar to those observed by ozonesondes (not shown), suggesting that convective transport and largescale ascending and descending motions in the study region are reasonably represented in the GEOS-4 and GEOS-5 meteorology. GMI/GEOS-4 and GMI/MERRA simulations also capture the observed large-scale variability in $\mathrm{O}_{3}$ and in the timing of $\mathrm{O}_{3}$ enhancements (not shown).

\section{Sources of springtime $\mathrm{O}_{3}$ enhancements in the lower troposphere over Beijing}

In this section we quantify the relative contributions to LT $\mathrm{O}_{3}$ over Beijing of different source types and source regions in the GEOS-Chem model. We focus on model simulations driven by GEOS-4 but also discuss GEOS-Chem/GEOS-5 results where necessary. The relative contributions allow us to better understand the factors and processes contributing to the observed $\mathrm{O}_{3}$ enhancements and distributions in the LT, and therefore they may provide insights into the model limitations in the representation of chemical, physical, and dynamical processes. Figure 6 shows the major sources of LT $\mathrm{O}_{3}$ over Beijing during April-May 2005 as a function of date and altitude, as simulated by GEOS-Chem/GEOS4. The plots show model results for tagged $\mathrm{O}_{3}$ tracers transported from the stratosphere and those produced in the Asian, African, European, and North American troposphere. Figure 7 presents the changes (decreases) in the LT $\mathrm{O}_{3}$ concentrations over Beijing when Asian, European, and North American fossil fuel emissions, global biomass burning emissions, or lightning $\mathrm{NO}_{x}$ emissions were turned off, individually, in GEOS-Chem/GEOS-4 and GEOS-Chem/GEOS5, relative to their standard simulations. Shown in Fig. 8 are the time series of temperature, total tagged $\mathrm{O}_{3}$, and tagged $\mathrm{O}_{3}$ tracer concentrations in the LT $(\sim 878$ or $840-915 \mathrm{hPa}$ in the model) over Beijing, as simulated by GEOS-Chem/GEOS-4. These figures provide a context for most of the discussions below.

\subsection{Contributions to $\mathrm{O}_{3}$ in the LT over Beijing of different source regions and emission types}

Ozone produced within Asia made a major contribution to LT $\mathrm{O}_{3}$ over Beijing during April-May 2005. The Asian troposphere contributed $\sim 10-46.6 \mathrm{ppbv}(\sim 17-66 \%)$ in earlymid-April and $\sim 9-81 \mathrm{ppbv}(\sim 15-88 \%)$ in late April and May (Fig. 6, top panels). The contribution was significantly higher in May than in April. This is consistent with the earlier result that relatively large enhancements of $\mathrm{O}_{3}$, which were observed by ozonesonde and aircraft and captured in model simulations, mostly occurred in late April and May. On the dates of these $\mathrm{O}_{3}$ enhancement events (e.g., 29 April and 3, 13, and 15 May), $\mathrm{LT} \mathrm{O}_{3}$ was predominantly produced within Asia ( 60-79.4 ppbv, or $\sim 81-88 \%)$. A modeling study by Sudo and Akimoto (2007) also suggested that LT $\mathrm{O}_{3}$ in Japan and coastal Chinese regions during the NASA Transport and Chemical Evolution over the Pacific (TRACEP) aircraft mission (spring 2001) was mainly produced within Asia and mostly in the planetary boundary layer.

The aforementioned relatively large enhancements of $\mathrm{O}_{3}$ were largely due to Asian fossil fuel emissions. When Asian fossil fuel emissions were turned off, the $\mathrm{LT}_{3}$ concentrations over Beijing decreased by $\sim 3.1-21.3 \mathrm{ppbv}$ in the GEOS-Chem/GEOS-4 simulation and by $\sim 3.0-25.3 \mathrm{ppbv}$ 

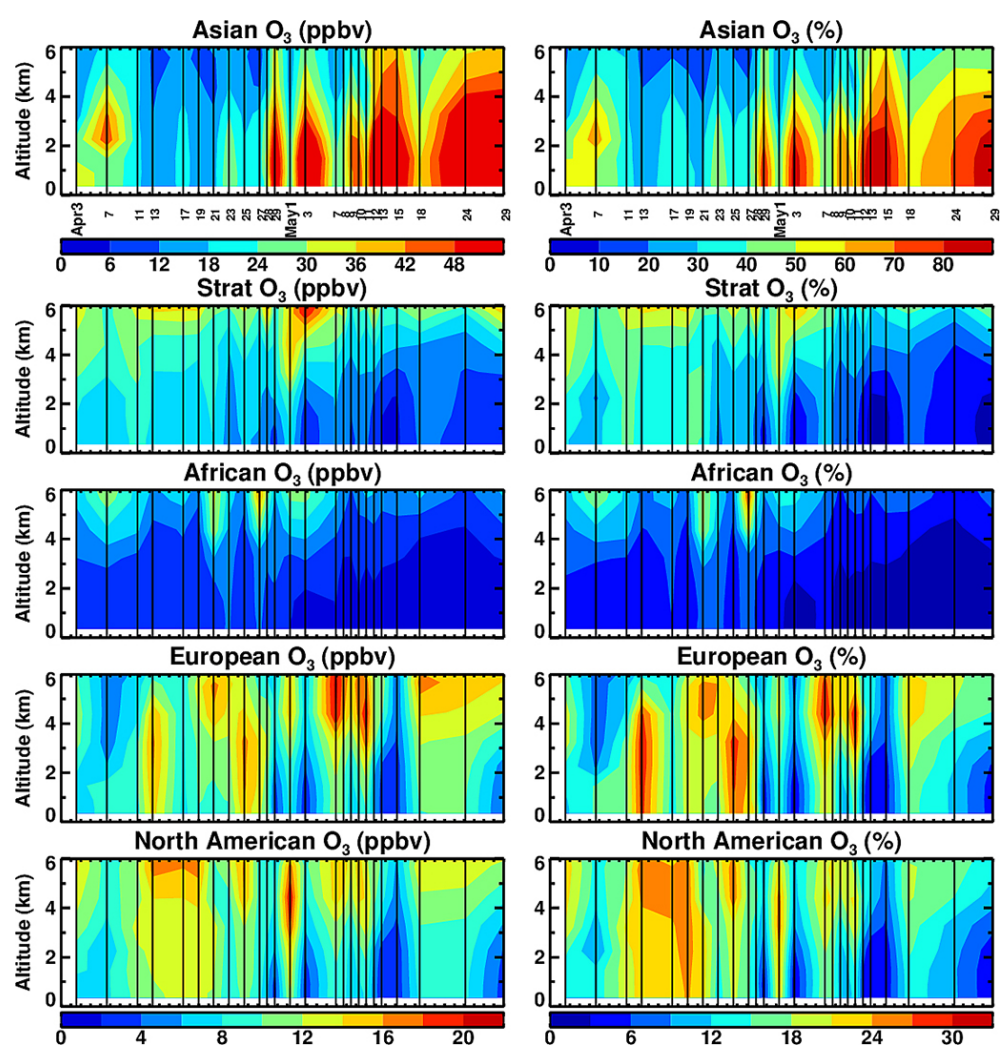

Figure 6. Major sources contributing to $\mathrm{O}_{3}(0-6 \mathrm{~km})$ over Beijing, as simulated by GEOS-Chem driven by the GEOS-4 meteorological fields during April-May 2005. The plots show time-height cross sections of concentrations (ppbv, left panels) and percentages (\%, right panels) of tagged $\mathrm{O}_{3}$ produced in the Asian, African, European, and North American troposphere, as well as $\mathrm{O}_{3}$ transported from the stratosphere. Model daily outputs are sampled at the location and dates (vertical lines) of ozonesonde soundings and/or aircraft measurements. Note the different color scales on color bars.

in the GEOS-Chem/GEOS-5 simulation in early-mid-April, and decreased by $\sim 2.2-42.4$ and $\sim 3.0-37.8$ ppbv, respectively, in late April and May (Fig. 7, top panels). The impact of Asian fossil fuel emissions was stronger in late April and May, especially during those days with large enhancements of $\mathrm{O}_{3}$. Without Asian fossil fuel emissions, $\mathrm{LT} \mathrm{O}_{3}$ reduced by $\sim 30-40$ ppbv on 29 April and 3, 13, and 15 May. To understand the influence of fossil fuel emissions (or $\mathrm{O}_{3}$ produced) in the subregions within Asia on $\mathrm{LT} \mathrm{O}_{3}$ over Beijing, additional sensitivity or tagged $\mathrm{O}_{3}$ simulations with refined emission (or $\mathrm{O}_{3}$ source) regions would be required. Nevertheless, the case study to be presented in the following section will provide insights into the effect of regional pollution transport in this regard.

Stratospheric contributions to $\mathrm{LT}_{3}$ over Beijing during April-May 2005 were significant (Fig. 6). They were $\sim 6.0$ $13.0 \mathrm{ppbv}(\sim 8.5-20.6 \%)$ in April and $\sim 1.6-19.8 \mathrm{ppbv}(\sim$ $2.1-23.8 \%$ ) in May, and increased with altitude. On average, stratospheric contributions were larger in April ( $\sim 7.6 \mathrm{ppbv})$ than in May $(\sim 5.7 \mathrm{ppbv})$. At the time of the aforementioned $\mathrm{O}_{3}$ enhancement events, stratospheric contributions were significantly reduced below $\sim 3 \mathrm{~km}(\sim 2 \mathrm{ppbv}, \sim 2 \%)$. The magnitude of the contributions of $\mathrm{O}_{3}$ produced within the African troposphere was lower than that of the stratospheric contributions (Fig. 6). The African troposphere contributed $\sim 2.4-16.5 \mathrm{ppbv}(\sim 3-28 \%) \mathrm{O}_{3}$ in April and $\sim 0.9$ $10.6 \mathrm{ppbv}(\sim 1-13 \%) \mathrm{O}_{3}$ in May.

The impact of biomass burning emissions on LT $\mathrm{O}_{3}$ over Beijing during this period was relatively small. When biomass burning emissions were turned off in GEOS-Chem, $\mathrm{O}_{3}$ concentrations decreased by $\sim 1 \pm 0.5 \mathrm{ppbv}$ in April and by $\sim 2 \pm 1 \mathrm{ppbv}$ in May, with a maximum decrease of $\sim 6.7$ ppbv on 7 April (Fig. 7). When lightning $\mathrm{NO}_{x}$ emissions were turned off, the $\mathrm{LT}_{3}$ concentrations fell by $\sim 1.3-9.1 \mathrm{ppbv}$ in the GEOS-Chem/GEOS-4 simulation and by $\sim 1.5-14.5 \mathrm{ppbv}$ in the GEOS-Chem/GEOS-5 simulation in April; in May, they decreased by $\sim 0.3-14.3 \mathrm{ppbv}$ and by $\sim 0.5-21.3$ ppbv (Fig. 7). The larger impact of lightning $\mathrm{NO}_{x}$ emissions in May reflects the seasonal increase in continental deep convection, which results in more frequent lightning. Relatively small effects $(\sim 3 \pm 1 \mathrm{ppbv})$ were seen at $\sim 1.5 \mathrm{~km}$, with an effect of $\sim 0.9 \pm 0.1 \mathrm{ppbv} \mathrm{O}_{3}$ at the time of large enhancements of $\mathrm{O}_{3}$.

The European and North American source regions and their anthropogenic emissions have important impacts on LT $\mathrm{O}_{3}$ over Beijing. Europe contributed $\sim 2-16.7 \mathrm{ppbv}(\sim 3-$ 

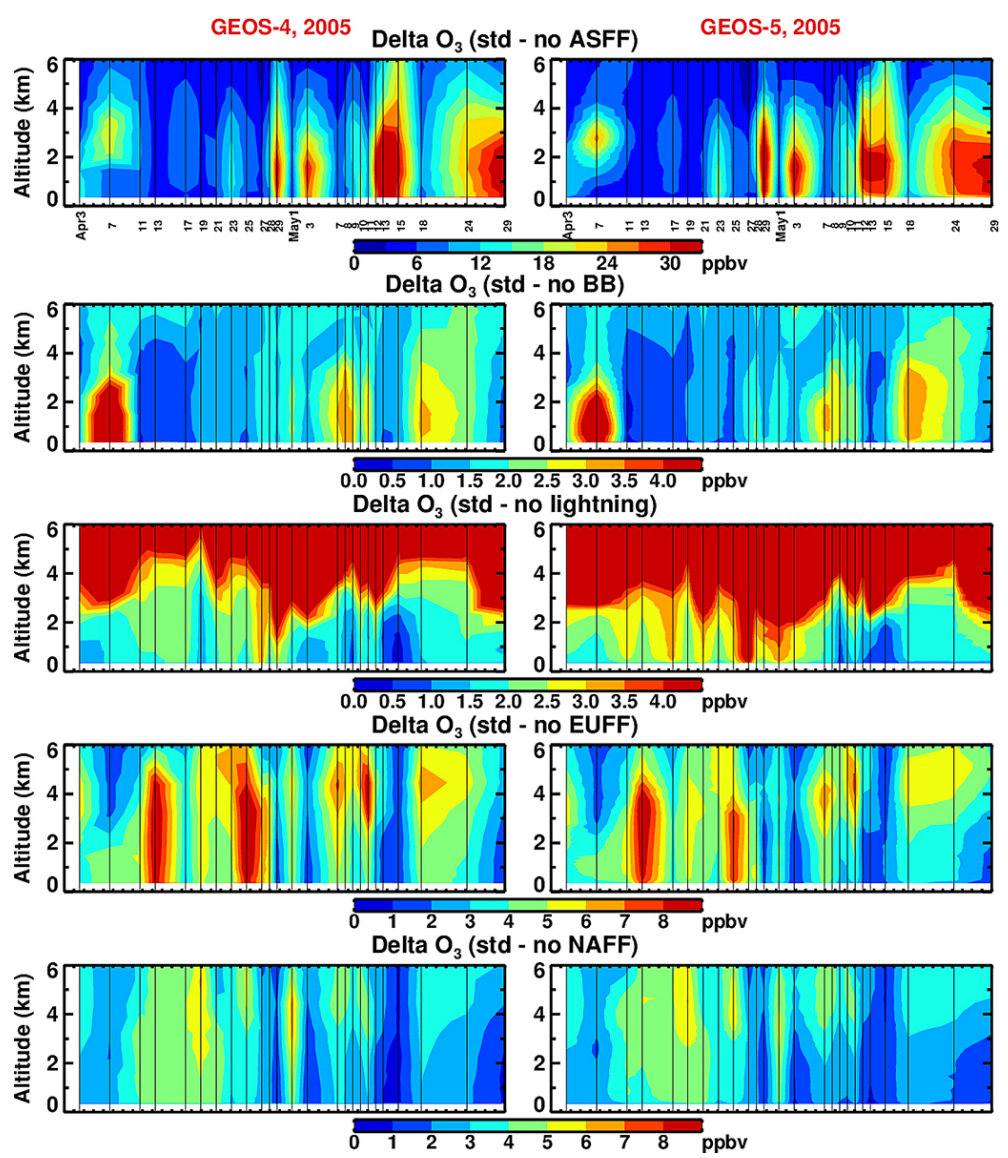

Figure 7. Decreases in the lower-tropospheric $\mathrm{O}_{3}$ concentrations (ppbv), as simulated by GEOS-Chem driven by the GEOS-4 (left panels) and GEOS-5 (right panels) meteorological fields, when Asian, European, and North American fossil fuel emissions, and biomass burning emissions or lightning $\mathrm{NO}_{x}$ emissions were suppressed, individually, relative to their standard simulations for April-May 2005. Note the different scales on color bars. Colors are saturated when values are out of range.

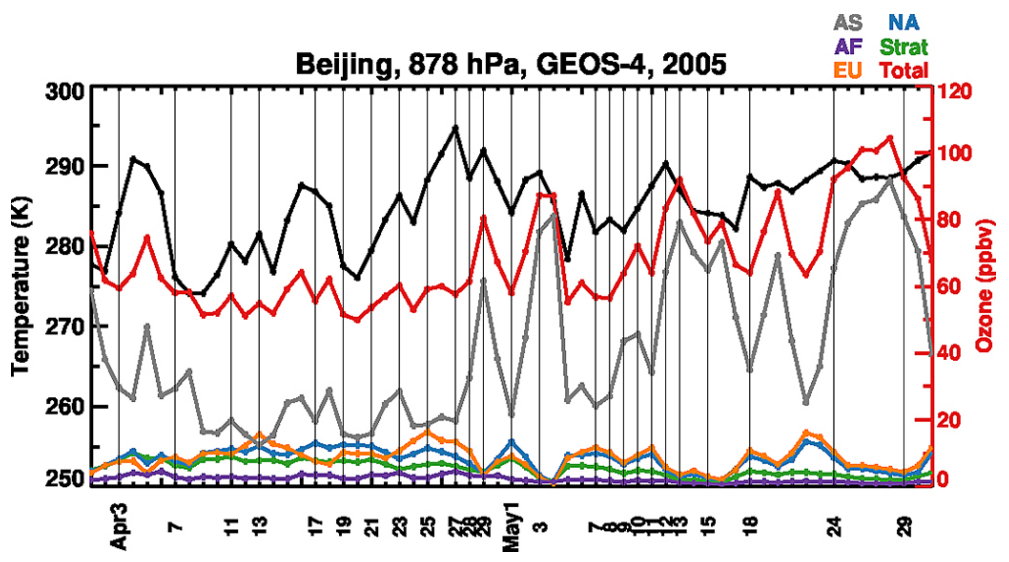

Figure 8. Time series of $\mathrm{O}_{3}$ concentrations (ppbv, red line) and temperature (black line) at $878 \mathrm{hPa}$ over Beijing in the GEOS-Chem model driven by the GEOS-4 meteorological fields. Also shown in the panel are simulated concentrations (ppbv) of tagged $\mathrm{O}_{3}$ produced in the Asian (AS, grey line), African (AF, purple line), European (EU, orange line), and North American (NA, blue line) troposphere and $\mathrm{O}_{3}$ transported from the stratosphere (Strat, green line). Vertical lines indicate dates with ozonesonde soundings and/or aircraft measurements.

$29.4 \%)$ of $\mathrm{O}_{3}$ in April and $\sim 2.5-20.8 \mathrm{ppbv}(\sim 3-29.9 \%)$ in May (Fig. 6). The contributions to $\mathrm{LT}_{3}$ below $4 \mathrm{~km}$ were larger in April. For these large enhancements of $\mathrm{O}_{3}$, the contributions from Europe were significantly reduced. 
Similarly, North America contributed $\sim 2.9-16.6 \mathrm{ppbv}(\sim$ $3.9-26.5 \%)$ in April and $\sim 2.5-20.3$ ppbv $(3.2-26.1 \%)$ in May, with much smaller contributions during $\mathrm{O}_{3}$ enhancement events (Fig. 6). When European fossil fuel emissions were turned off, the LT $\mathrm{O}_{3}$ concentrations over Beijing decreased by $\sim 1.3-10$ ppbv in April and $\sim 1-8$ ppbv in May (Fig. 7). The decreases were $\sim 1-6 \mathrm{ppbv}$ in April and $\sim 0.6-$ $6 \mathrm{ppbv}$ in May when North American fossil fuel emissions were turned off. Again, the impacts of European and North American fossil fuel emissions were minimal $(<\sim 1 \mathrm{ppbv})$ during the events of large enhancements of $\mathrm{O}_{3}$.

Figure 8 shows the time series of total $\mathrm{O}_{3}$, tagged $\mathrm{O}_{3}$, and temperature in the LT $(\sim 878 \mathrm{hPa}, \sim 1.5 \mathrm{~km})$ over Beijing in GEOS-Chem-GEOS4. Occurrences of these $\mathrm{O}_{3}$ enhancements were accompanied by significantly increased contributions of $\mathrm{O}_{3}$ produced in the Asian troposphere and often associated with warm air masses. On the days with relatively large $\mathrm{O}_{3}$ enhancements observed (29 April and 3, 13, and 15 May), the contributions of $\mathrm{O}_{3}$ from the Asian troposphere were $62.1 \mathrm{ppbv}(77.4 \%), 76.0 \mathrm{ppbv}(87.0 \%)$, $79.4 \mathrm{ppbv}(86.4 \%)$, and $64.0 \mathrm{ppbv}(87.2 \%)$, respectively. By contrast, at the time of these events, the contributions from Europe and North America were largely reduced. Also, compared to the more prominent contributions from Europe ( $11.6 \mathrm{ppbv})$ and North America ( 11.6 ppbv) in early April, they were smaller in late April and May, with an average of $\sim 8.2$ and $\sim 8.0 \mathrm{ppbv}$, respectively.

As Beijing is located at midlatitudes in eastern Asia $\left(40^{\circ} \mathrm{N}\right)$, air masses originating from Europe and North America arrived as a result of large-scale subsidence associated with the Siberian anticyclone. Previous studies have shown that European anthropogenic emissions contribute significantly to the Asian outflow in the LT at latitudes north of $35^{\circ} \mathrm{N}$ (Bey et al., 2001a; Liu et al., 2003). As the Siberian high gradually weakened in spring and its center shifted westward, air masses from these regions had a reduced influence. Meanwhile, the western Pacific subtropical high developed and its center moved northwestward. As a result, the northward transport of warmer air masses from southern China and along the Asian Pacific rim became more vigorous. An examination of the GEOS-4 and GEOS-5 meteorological fields shows that Beijing was mostly under the influence of southwesterly flow on the days with observed ozone enhancements. This is consistent with the stronger influence of Asian sources and more frequent occurrences of large $\mathrm{O}_{3}$ enhancements in late April and May.

\subsection{Ozone enhancements in the lower troposphere: a case study}

In order to better understand the transport pathways for $\mathrm{O}_{3}$ pollution and the vertical extent of $\mathrm{O}_{3}$ enhancements over Beijing, we examine the largest $\mathrm{O}_{3}$ enhancement observed by both the TAPTO-China ozonesonde and MOZAIC aircraft during April-May 2005. Figure 9 shows the vertical

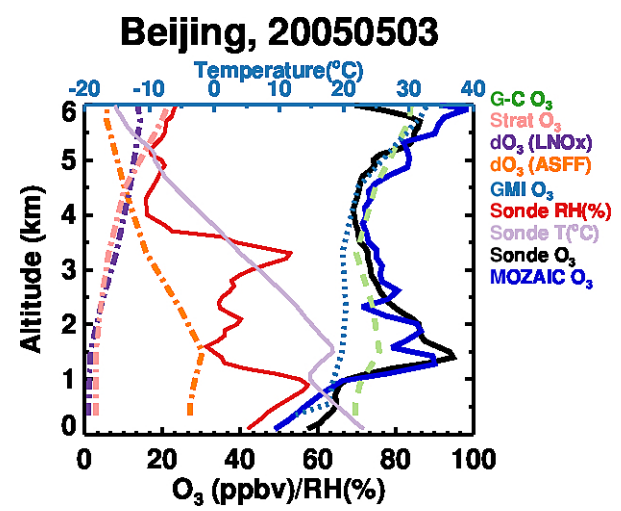

Figure 9. Vertical profiles of $\mathrm{O}_{3}$ mixing ratios (ppbv) over Beijing from ozonesonde (black solid line) and MOZAIC aircraft (blue solid line) measurements on 3 May 2005 compared to those simulated by GEOS-Chem/GEOS-4 (green dashed line) and GMI/GEOS-4 (blue dotted line). Sonde-observed RH (\%) and temperature $\left({ }^{\circ} \mathrm{C}\right)$ are shown as red solid line and purple solid line, respectively. Decreases in $\mathrm{O}_{3}$ concentrations (ppbv) when Asian fossil fuel or lightning $\mathrm{NO}_{x}$ emissions were suppressed, relative to the standard simulation, are shown as orange and purple dotdashed lines, respectively. $\mathrm{O}_{3}$ transported down from the stratosphere (ppbv) is shown as pink dot-dashed line.

profiles of $\mathrm{O}_{3}$ over Beijing from the TAPTO ozonesonde and MOZAIC aircraft measurements in comparison with those simulated by GEOS-Chem/GEOS-4 and GMI/GEOS-4 on 3 May 2005. Also shown are observed RH, temperature, and $\mathrm{O}_{3}$ sources as determined by GEOS-Chem tagged $\mathrm{O}_{3}$ and sensitivity simulations.

Ozonesonde and aircraft measurements of $\mathrm{O}_{3}(0-6 \mathrm{~km})$ agree within $\sim 2 \%$ on average and show similar structures in their vertical distributions. The ozone mixing ratio was lowest near the surface and increased with altitude below $\sim 1.5 \mathrm{~km}$, where it reached a maximum (94.7 and $90 \mathrm{ppbv}$ in ozonesonde and aircraft measurements, respectively), and then decreased with altitude from $\sim 1.5$ to $\sim 4 \mathrm{~km}$. The rapid increase in $\mathrm{O}_{3}$ concentrations from $\sim 1$ up to $\sim 1.5 \mathrm{~km}$ was accompanied by a temperature inversion observed by ozonesonde. This temperature inversion inhibited the vertical mixing and transport of the air, trapping the air mass containing high levels of $\mathrm{O}_{3}$ (and its precursors) at this level. The presence of the inversion also suggests that the high $\mathrm{O}_{3}$ at $\sim 1.5 \mathrm{~km}$ was not transported from the local boundary layer via vertical mixing. Rather, backward trajectory calculations using the NOAA HYSPLIT (Hybrid SingleParticle Lagrangian Integrated Trajectory) model (Draxler and Rolph, 2014; Rolph, 2014) show that the air mass was transported downward from a higher altitude $(\sim 3 \mathrm{~km})$ and stayed at about $1.4 \mathrm{~km}$ for 2 days before arriving at the $1.4 \mathrm{~km}$ level over Beijing (Fig. 10).

The relatively low $\mathrm{O}_{3}$ below $1 \mathrm{~km}$ was likely due to chemical titration by local fresh $\mathrm{NO}_{x}$ emissions. The 5-day backward trajectory arriving at $150 \mathrm{~m}$ over Beijing indicates that 
NOAA HYSPLIT MODEL Backward trajectories ending at 0600 UTC 03 May 05 CDC1 Meteorological Data

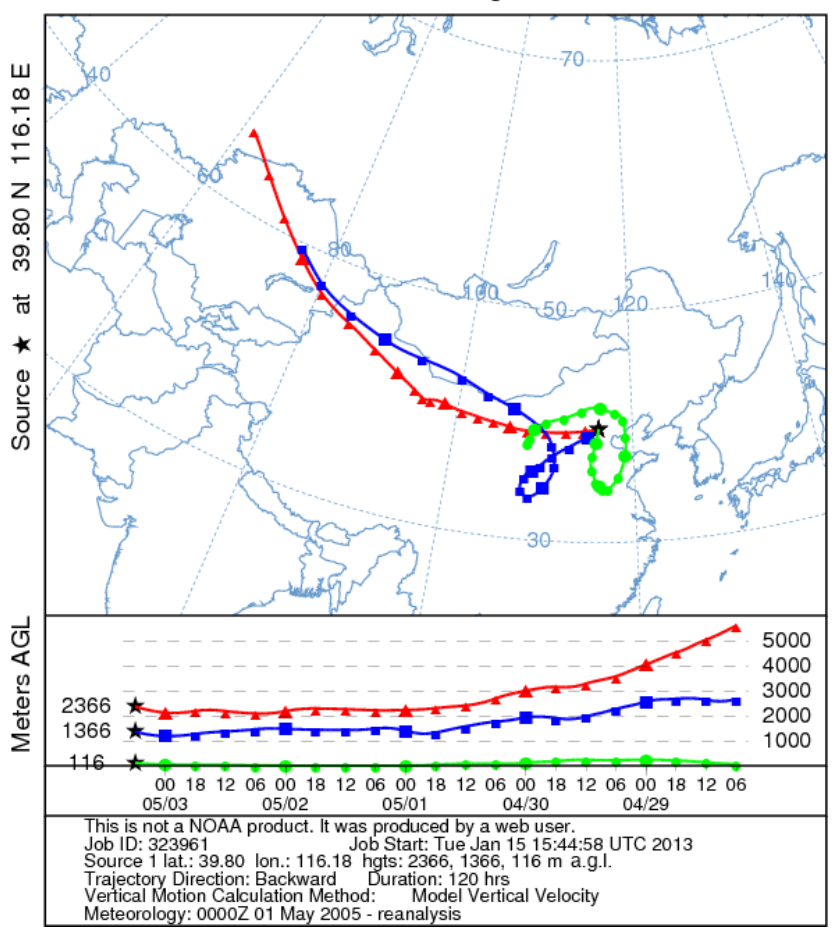

Figure 10. Five-day back trajectories arriving at the altitudes of $150 \mathrm{~m}$ (green line), $1400 \mathrm{~m}$ (blue line), and $2400 \mathrm{~m}$ (red line) over Beijing at 14:00 local time on 3 May 2005. AGL and hgts denote the altitudes above ground level. The ozonesonde station is $34 \mathrm{~m}$ a.s.l. Note that $1366 \mathrm{~m}$ a.g.l. corresponds to $1400 \mathrm{~m}$ a.s.l. and so on.

the air mass stayed near the surface during the days prior to its arrival (Fig. 10), providing optimal conditions for chemical titration.

The GEOS-Chem/GEOS-4 simulation showed an enhancement of $\mathrm{O}_{3}$ at $\sim 1.5 \mathrm{~km}$ on 3 May but significantly underestimated its magnitude by $\sim 10-15$ ppbv (Fig. 9). This is partly attributed to the inability of a large-scale model to resolve the local temperature inversion (not shown). The simulation reproduced the observations above $2.5 \mathrm{~km}$ reasonably well, but overestimated the observations (by $\sim 5-10 \mathrm{ppbv}$ ) below $1 \mathrm{~km}$, presumably because chemical titration was not well represented and there was too much vertical mixing due to the lack of a temperature inversion in the model. The GMI/GEOS-4 simulation reproduced the relatively low $\mathrm{O}_{3}$ concentrations near the surface better. However, it failed to capture the $\mathrm{O}_{3}$ enhancements at $\sim 1.5 \mathrm{~km}$. The LT $\mathrm{O}_{3}$ concentrations simulated by GMI/GEOS-4 are much lower than the observations, with the largest discrepancy $(\sim 26.9 \mathrm{ppbv})$ at $\sim 1.5 \mathrm{~km}$.

Model simulations suggest that this $\mathrm{LT} \mathrm{O}_{3}$ enhancement over Beijing was largely due to Asian fossil fuel emissions. Without Asian fossil fuel emissions in the GEOSChem/GEOS-4 model, the simulated $\mathrm{O}_{3}$ concentrations in the LT decreased by $\sim 30 \%$ (Fig. 9). The impact of the Asian fossil fuel emissions was largest ( $\sim 30 \mathrm{ppbv}, 40 \%)$ at $\sim 1.5 \mathrm{~km}$, where $\mathrm{LT} \mathrm{O}_{3}$ concentrations reached a maximum. In addition, tagged $\mathrm{O}_{3}$ simulations showed that $79.6 \%$ of $\mathrm{O}_{3}$ at $\sim 1.5 \mathrm{~km}$ originated from the Asian troposphere (not shown). When lightning $\mathrm{NO}_{x}$ emissions were suppressed, the decreases in $\mathrm{LT} \mathrm{O}_{3}$ over Beijing increased with altitude, with the smallest decreases $(\sim 1.2 \mathrm{ppbv}, \sim 1.7 \%)$ below $\sim$ $1.5 \mathrm{~km}$. Similarly, the contributions of stratospheric $\mathrm{O}_{3}$ increased with altitude, with a small contribution $(\sim 2.9 \mathrm{ppbv}$, $\sim 4 \%$ ) at $\sim 1.5 \mathrm{~km}$, where the largest enhancement of $\mathrm{O}_{3}$ occurred. Therefore, this $\mathrm{LT} \mathrm{O}_{3}$ enhancement was mainly due to the regional anthropogenic pollution within Asia.

The GEOS4 assimilated meteorological data driving the GEOS-Chem model indicate that strong southwesterly winds prevailed over Beijing in the LT on 2-3 May (Figs. 11, 12). Meanwhile, a low-pressure center in the LT at $\sim 43-53^{\circ} \mathrm{N}$, $120-140^{\circ} \mathrm{E}$ put the area north of Beijing under the influence of northwesterly winds. The southwesterly and northwesterly winds met just north of Beijing at around $43^{\circ} \mathrm{N}$, forming a convergence zone. As part of the western Pacific subtropical high developing around $15-30^{\circ} \mathrm{N}$, strong southwesterly winds over southern and eastern China could have readily swept the pollutants in their pathway into Beijing. Indeed, an area of high CO (>200 ppbv) was located to the southwest of the North China Plain on 2-3 May at $878 \mathrm{hPa}$. The air mass stayed in this high-CO area for a couple of days before arriving at $1.4 \mathrm{~km}$ over Beijing (Fig. 10), where the $\mathrm{O}_{3}$ enhancement was observed by both sonde and aircraft, as well as simulated by the model. By contrast, the air mass arriving at $2.4 \mathrm{~km}$ came straight from the west, where air was cleaner and thus had much lower $\mathrm{O}_{3}$. The high-CO area was largest near the surface and became smaller with altitude. High CO concentrations were seen in the model simulations up to $\sim 797 \mathrm{hPa}$. No high-CO plumes were found at $\sim 704 \mathrm{hPa}$ over eastern Asia on 2-3 May in the model (not shown). By 3 May, Beijing was at the center of the high- $\mathrm{O}_{3}$ area (> $72 \mathrm{ppbv})$ in the LT (797 and $878 \mathrm{hPa}$, Fig. 12). The $\mathrm{O}_{3}$ concentrations were also relatively lower $(\sim 68 \pm 4 \mathrm{ppbv})$ near the surface $(942 \mathrm{hPa})$ or at a higher altitude $(704 \mathrm{hPa})$.

\section{Summary and conclusions}

We have characterized the vertical distribution of lowertropospheric $\mathrm{O}_{3}$ over Beijing using observations from 16 ozonesonde soundings made during the TAPTO-China field campaign in April-May 2005, as well as from MOZAIC aircraft ascending and descending profiles over 13 days in this period. A particular focus was placed on the origin of $\mathrm{O}_{3}$ enhancements in the lower troposphere $(0-6 \mathrm{~km})$. We used a global 3-D chemistry and transport model (GEOSChem CTM) driven by assimilated meteorological fields from the NASA Goddard Earth Observing System (GEOS-4 and GEOS-5) to interpret these characteristics and quantify 


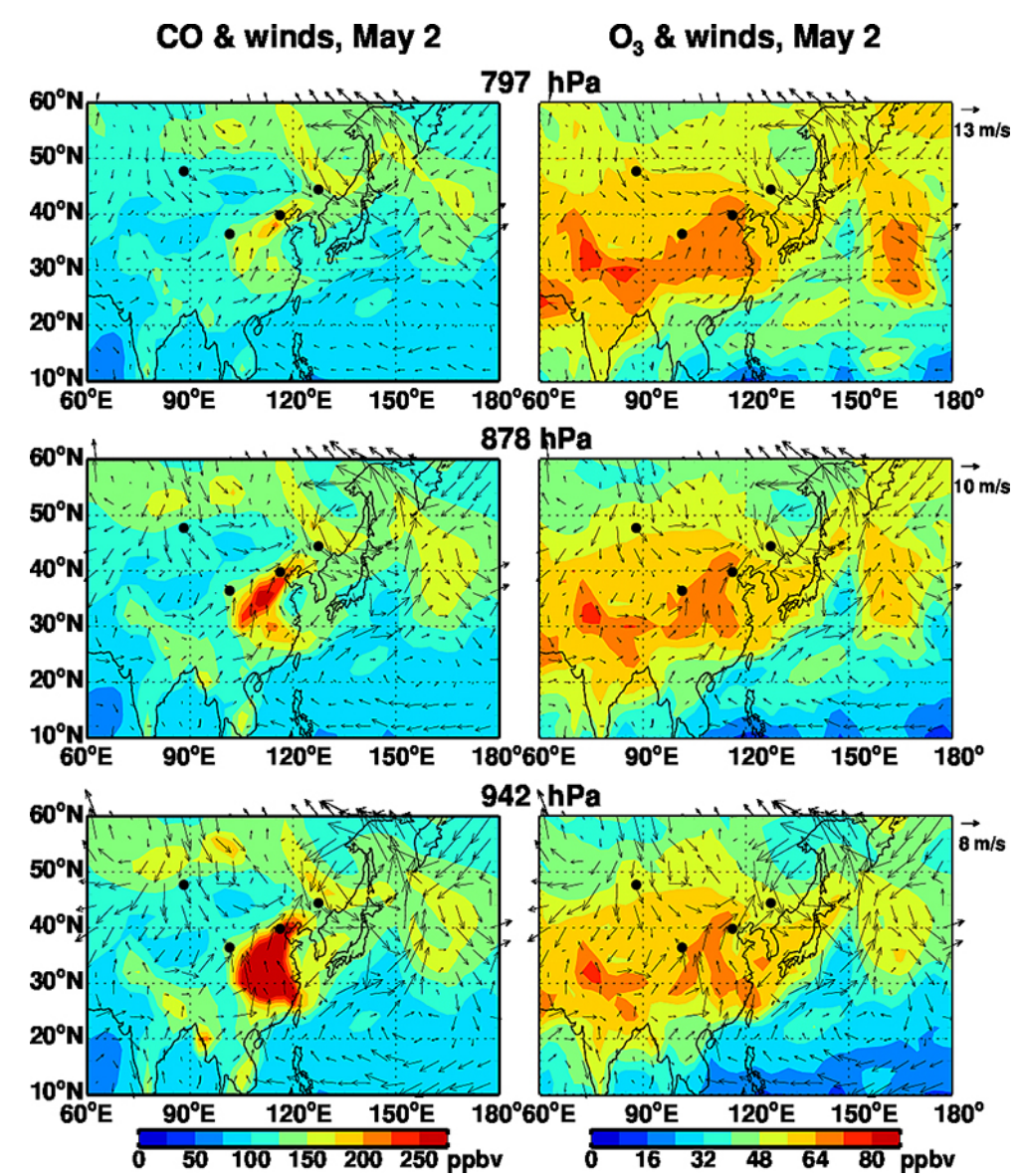

Figure 11. Average $\mathrm{CO}$ concentrations (ppbv, left panels) and $\mathrm{O}_{3}$ concentrations (ppbv, right panels) in the lower troposphere (797 hPa, top panels; $878 \mathrm{hPa}$, middle panels; $942 \mathrm{hPa}$ bottom panels) over eastern Asia on 2 May 2005, as simulated by GEOS-Chem driven by the GEOS-4 meteorological fields. Dots denote the locations of four ozonesonde stations shown in Fig. 1. Arrows are wind vectors. Note the different arrow scales for wind vectors at different levels.

the sources contributing to $\mathrm{O}_{3}$ and its enhancements in the springtime LT over Beijing. We also used the output of the Global Modeling Initiative (GMI) CTM for comparison with $\mathrm{O}_{3}$ observations.

The average observed profile of the $\mathrm{O}_{3}$ mixing ratio in the LT over Beijing during April-May 2005 ranged from $\sim 44$ to $67 \mathrm{ppbv}$, with an enhancement at the altitude of $\sim 1.5 \mathrm{~km}$ and a relatively low abundance near the surface. The relatively high average $\mathrm{O}_{3}$ concentrations at $\sim 1.5 \mathrm{~km}$ were due to frequently observed elevated $\mathrm{O}_{3}$ levels (up to $94.7 \mathrm{ppbv}$ in soundings and $130.3 \mathrm{ppbv}$ in MOZAIC aircraft measurements). Such enhancements were observed at this altitude in 15 out of the 25 days with observations during this period. Ozone enhancements were more frequently observed by ozonesonde in late April and May compared to early and mid-April. This relates to the northward transport of pollution in eastern China to the LT over Beijing as a result of a weakening of the Siberian high and the onset of the Asian summer monsoon. It also implies that an earlier onset of the Asian summer monsoon would cause more $\mathrm{O}_{3}$ enhancement events in the LT over the North China Plain in late spring and early summer.

The GEOS-Chem model driven by GEOS-4 and GEOS-5 assimilated meteorological fields adequately reproduced the average vertical distribution of $\mathrm{LT}_{3}$ and captured the timing of the observed $\mathrm{O}_{3}$ enhancement events over Beijing during April-May 2005, but both simulations underestimated the magnitude of these enhancements. On the other hand, GEOS-Chem overestimated the observed low $\mathrm{O}_{3}$ concentrations near the surface. The GMI model driven by GEOS-4 and MERRA resolved the average $\mathrm{O}_{3}$ concentrations near the surface better but was less successful in reproducing the enhancement of average $\mathrm{O}_{3}$ concentrations at $\sim 1.5 \mathrm{~km}$. Nevertheless, GMI did capture the timing of the major $\mathrm{O}_{3}$ enhancement events observed. Both GEOS-Chem and GMI were successful in reproducing temporal fluctuations of observed $\mathrm{O}_{3}$ because they are driven by assimilated meteorological fields. The fact that they did not capture the surface low or the $1.5 \mathrm{~km}$ peak likely resulted from a combination of an inability to represent the chemical regime at the surface (i.e., $\mathrm{NO}_{x^{-}}$ 


\section{CO \& winds, May $3 \quad \mathrm{O}_{3}$ \& winds, May 3}

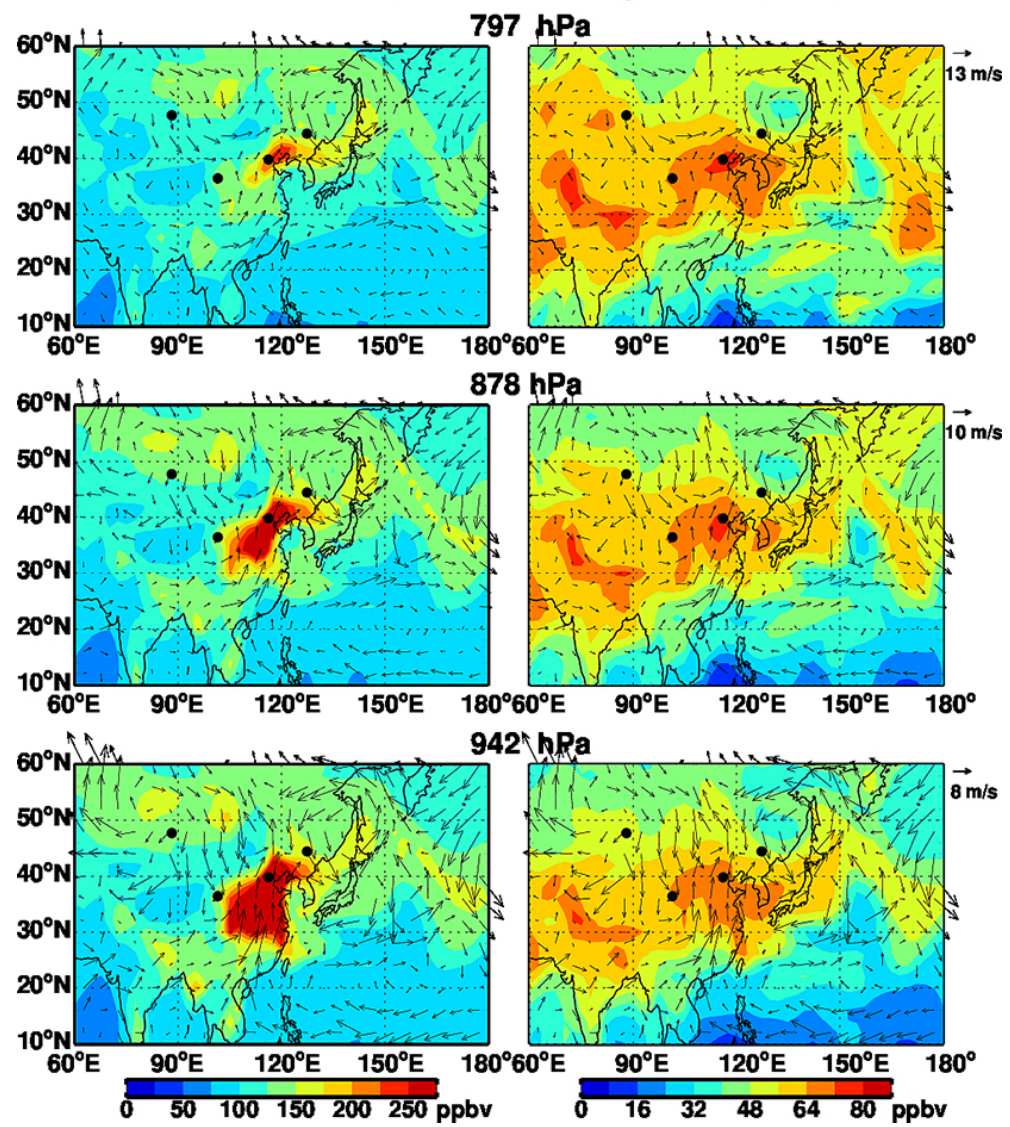

Figure 12. Same as Fig. 11, but for 3 May 2005.

driven titration) due to low spatial resolution and overly vigorous vertical transport (i.e., lack of a temperature inversion at an altitude of $\sim 1.5 \mathrm{~km}$ ).

We investigated the sources contributing to the $\mathrm{LT} \mathrm{O}_{3}$ enhancements observed over Beijing during April-May 2005 by tagging $\mathrm{O}_{3}$ produced in different source regions in the GEOS-Chem/GEOS-4 model and by conducting model sensitivity calculations. We found that these $\mathrm{O}_{3}$ enhancements were predominantly attributed to $\mathrm{O}_{3}$ produced within Asia, especially for relatively large enhancements $(\sim 81-88 \%)$. For the large enhancements, the $\mathrm{O}_{3}$ concentrations at $\sim$ $1.5 \mathrm{~km}$ were reduced by $\sim 30-40 \mathrm{ppbv}$ when Asian fossil fuel emissions were suppressed within the model. Contributions of $\mathrm{O}_{3}$ from outside Asia were small during these $\mathrm{O}_{3}$ events. However, long-range transport of $\mathrm{O}_{3}$ (and its precursors) from Europe and North America had important impacts on $\mathrm{LT}_{3}$ over Beijing during non-event periods, especially in April. The two alternating regimes of transport reflect the springtime transition from winter to summer monsoon in eastern Asia.

A case study of the $\mathrm{O}_{3}$ enhancements at $\sim 1.5 \mathrm{~km}$ on 3 May 2005 showed that the event was largely attributed to Asian fossil fuel emissions (34\%). Backward trajectory cal- culations suggested that the air mass stayed in the LT to the southwest of Beijing for a couple of days before arriving at $\sim 1.4 \mathrm{~km}$ over Beijing. Elevated $\mathrm{CO}$ levels were found in the model on 2 and 3 May in the area where the air mass stayed before reaching Beijing. The model simulations showed that Beijing was at the center of the high- $\mathrm{O}_{3}$ area in the LT $(\sim 878$ to $797 \mathrm{hPa}$ ) by $3 \mathrm{May}$, with prevailing strong southwesterly winds that swept $\mathrm{O}_{3}$ and its precursors downwind to Beijing.

We find that the ozonesonde and aircraft observations of springtime $\mathrm{O}_{3}$ in the LT over Beijing are qualitatively consistent with the current understanding of tropospheric chemistry and transport as represented by the GEOS-Chem model. Using the same model driven by different meteorological fields (GEOS-4 and GEOS-5) does not alter our conclusion. However, current global models (e.g., GEOS-Chem and GMI) have difficulty in quantitatively reproducing the observed enhancements and depletions of $\mathrm{LT}_{3}$ over Beijing. Model simulations at higher resolutions would resolve regional meteorology and transport better with respect to the topography in the North China Plain and chemical transformation, such as the titration of $\mathrm{O}_{3}$ by NO. Models could also be further evaluated by increasing satellite observations as well as multiyear ozonesonde (Wang et al., 2012) and air- 
craft measurements (Ding et al., 2008). Such efforts would improve our quantitative understanding of the origin of tropospheric $\mathrm{O}_{3}$ and elevated $\mathrm{O}_{3}$ events over the North China Plain, allowing a better projection of regional $\mathrm{O}_{3}$ pollution and its global impact. 


\section{Appendix A: GEOS-Chem CTM}

An earlier version of the GEOS-Chem model that we applied to the analysis of ozonesonde $\mathrm{O}_{3}$ observations was described in the Appendix of Zhang et al. (2012). A similar description is included here for completeness, but for version v9-01-02 and with a different configuration. We drive the GEOS-Chem model with the GEOS-4 and GEOS-5 assimilated meteorological observations from the GEOS of the NASA GMAO. The original description and evaluation of GEOS-Chem as applied to tropospheric $\mathrm{O}_{3}-\mathrm{NO}_{x}-\mathrm{VOCs}$ (volatile organic compounds) chemistry was presented by Bey et al. (2001a) and a description of the coupled oxidantaerosol simulation was given by Park et al. (2004). A number of previous studies have applied the model to tropospheric $\mathrm{O}_{3}$ in various regions of the world, including the Asian and western Pacific (e.g., Bey et al., 2001b; Liu et al., 2002), the Middle East (e.g., Li et al., 2001; Liu et al., 2009), the United States (e.g., Fiore et al., 2002; Zhang et al., 2008; Hudman et al., 2009), the Atlantic (e.g., Li et al., 2002), and the tropics (e.g., Martin et al., 2002; Nassar et al., 2009; Zhang et al., 2011).

The temporal resolution of the GEOS-4 and GEOS-5 meteorological data is $6 \mathrm{~h}(3 \mathrm{~h}$ for surface variables and mixing depth). GEOS-4 has a native resolution of $1^{\circ}$ latitude by $1.25^{\circ}$ longitude with 55 vertical levels between the surface and $0.01 \mathrm{hPa}$ and 8 vertical levels between $0-6 \mathrm{~km}$. GEOS-5 has a higher native resolution of $0.5^{\circ}$ latitude by $0.667^{\circ}$ longitude with 72 levels overall in the vertical and 23 vertical levels between 0 and $6 \mathrm{~km}$. For computational expediency, horizontal resolutions are degraded to $2^{\circ}$ latitude by $2.5^{\circ}$ longitude for input to GEOS-Chem. In addition, vertical levels above $50 \mathrm{hPa}$ (GEOS-4) or $80 \mathrm{hPa}$ (GEOS-5) are merged to result in 30 (GEOS-4) or 47 (GEOS-5) vertical levels in total. A major difference between GEOS-4 and GEOS-5 is the parameterization scheme for convection. GEOS-4 uses the parameterization scheme of Zhang and McFarlane (1995) for deep convection and that of Hack (1994) for shallow convection. Convection in GEOS-5 is based on the relaxed Arakawa-Schubert parameterization scheme (Moorthi and Suarez, 1992). Previous model simulations of ${ }^{222} \mathrm{Rn}$ (Zhang et al., 2011) and CO (Liu et al., 2010) indicate that tropical deep convection is significantly deeper in GEOS-4 than in GEOS-5. GEOS-Chem assumes rapid vertical mixing within the mixing layers diagnosed by GEOS.
The GEOS-Chem model includes 87 chemical species and transports 43 chemical tracers to describe tropospheric $\mathrm{O}_{3}-$ $\mathrm{NO}_{x}$-VOCs-aerosol chemistry. Anthropogenic emissions are based on the Global Emission Inventory Activity (GEIA) (Benkovitz et al., 1996), overwritten with $\mathrm{NO}_{x}, \mathrm{CO}$, and $\mathrm{SO}_{x}$ from the Emission Database for Global Atmospheric Research (EDGAR) inventory (Olivier and Berdowski, 2001) and from various regional emissions inventories as described by Nassar et al. (2009). Anthropogenic emissions in Asia are from the Streets 2000 inventory (Streets et al., 2003), with anthropogenic $\mathrm{CO}$ emissions in China updated by the Streets 2001 inventory (Streets et al., 2006). These base inventory emissions are scaled to our 2005 simulation year, following van Donkelaar et al. (2008). The 2005 anthropogenic emission for Asia $\left(0-60^{\circ} \mathrm{N}, 65-150^{\circ} \mathrm{E}\right)$ is $10.1 \mathrm{Tg} \mathrm{Nyr}^{-1}$ for $\mathrm{NO}_{x}$ and $271.9 \mathrm{Tg} \mathrm{yr}^{-1}$ for CO. Biofuel emissions follow Yevich and Logan (2003). Biogenic VOC emissions are based on the Model of Emissions of Gases and Aerosol from Nature (MEGAN) inventory (Guenther et al., 2006). Biomass burning emissions are based on the Global Fire Emissions Database version 2 (GFEDv2), which resolves interannual variability (van der Werf et al., 2006). The monthly GFEDv2 emissions were resampled to an 8-day time step using MODIS fire hot spots (Giglio et al., 2003; Nassar et al., 2009).

Lightning NO emissions in GEOS-Chem are calculated locally in deep convection events with the scheme of Price and Rind (1992) that links flash rates to convective cloud top heights. The spatial distribution of lightning averaged over 11 years in the model is constrained to match the climatological (11-year) satellite observations of lightning flash rates from the Optical Transient Detector-Lightning Imaging Sensor (OTD-LIS) High Resolution Monthly Climatology (HRMC v2.2) product by applying a local monthly rescaling factor (Sauvage et al., 2007; Nassar et al., 2009). The interannual variability of the lightning $\mathrm{NO}_{x}$ emissions as represented by the model is retained, with approximately $6 \mathrm{Tg} \mathrm{Nyr}^{-1}$ released globally (Sauvage et al., 2007; Nassar et al., 2009). The vertical distribution of lightning $\mathrm{NO}_{x}$ emissions follows Pickering et al. (1998), with most of $\mathrm{NO}_{x}$ in the upper troposphere (55-75\% above $\left.8 \mathrm{~km}\right)$. The model uses the linearized stratospheric $\mathrm{O}_{3}$ chemistry scheme (Linoz or linearized ozone) of McLinden et al. (2000). Liu et al. (2015) previously suggested that Linoz in a CTM driven with the GEOS-4 and GEOS-5 assimilated meteorological fields yields reasonable impacts of cross-tropopause transport on the lower troposphere. 
Acknowledgements. This work was supported by the NASA Atmospheric Composition Modeling and Analysis Program (ACMAP) and NASA Modeling, Analysis, and Prediction Program (MAP). Ozonesonde data were obtained with support from the National Science Foundation of China. We thank the personnel at the Beijing ozonesonde station for helping with the launching of ozonesondes. The authors acknowledge the strong support of the European Commission, Airbus, and the airlines (Lufthansa, Air France, Austrian, Air Namibia, China Airlines, and Cathay Pacific so far) who have carried the MOZAIC or IAGOS equipment and performed the maintenance since 1994. MOZAIC is presently funded by INSU-CNRS (France), Météo-France, CNES, Université Paul Sabatier (Toulouse, France), and the Research Center Jülich (FZJ, Jülich, Germany). IAGOS has been and is additionally funded by the EU projects IAGOS-DS and IAGOS-ERI. The MOZAIC-IAGOS data are available via the CNES/CNRS-INSU Ether web site http://www.pole-ether.fr. The NASA Center for Computational Sciences (NCCS) provided supercomputing resources. The GEOS-Chem model is managed by the Atmospheric Chemistry Modeling Group at Harvard University with support from NASA ACMAP and MAP. The GMI model is managed by Jose Rodriguez (Project Scientist) and Susan Strahan (Project Manager) at the NASA Goddard Space Flight Center with support from MAP. We thank Meiyun Lin and two anonymous reviewers for their comments and suggestions, which helped improve the manuscript.

Edited by: R. Cohen

\section{References}

Allen, D., Pickering, K., Duncan, B., and Damon, M.: Impact of lightning NO emissions on North American photochemistry as determined using the Global Modeling Initiative (GMI) model, J. Geophys. Res., 115, D22301, doi:10.1029/2010JD014062, 2010.

An, X., Zhu, T., Wang, Z., Li, C., and Wang, Y.: A modeling analysis of a heavy air pollution episode occurred in Beijing, Atmos. Chem. Phys., 7, 3103-3114, doi:10.5194/acp-7-3103-2007, 2007.

Benkovitz, C. M., Scholtz, M. T., Pacyna, J., Tarrason, L., Dignon, J., Voldner, E. C., Spiro, P. A., Logan, J. A., and Graedel, T. E.: Global gridded inventories of anthropogenic emissions of sulfur and nitrogen, J. Geophys. Res., 101, 29239-29253, doi:10.1029/96JD00126, 1996.

Bey, I., Jacob, D. J., Logan, J. A., and Yantosca, R. M.: Asian chemical outflow to the Pacific in spring: Origins, pathways, and budgets, J. Geophys. Res., 106, 23097-23113, doi:10.1029/2001JD000806, 2001a.

Bey, I., Jacob, D. J., Yantosca, R. M., Logan, J. A., Field, B. D., Fiore, A. M., Li, Q., Liu, H., Mickley, L. J., and Schultz, M. G.: Global modeling of tropospheric chemistry with assimilated meteorology: Model description and evaluation, J. Geophys. Res., 106, 23073-23095, doi:10.1029/2001JD000807, 2001b.

Bloom, S., da Silva, A., Dee, D., Bosilovich, M., Chern, J., Pawson, S., Schubert, S., Sienkiewicz, M., Stajner, I., and Tan, W.-W., and Wu, M.-L.: Documentation and validation of the Goddard Earth Observing System (GEOS) data assimilation system-Version 4, Technical Report Series on Global Modeling and Data Assim- ilation, Vol. 26, No. NASA/TM-2005-104606, Greenbelt, MD, USA, 2005.

Blumenthal, D., White, W., and Smith, T.: Anatomy of a Los Angeles smog episode: Pollutant transport in the daytime sea breeze regime, Atmos. Environ., 15, 893-907, 1978.

Chan, C., Chan, L., and Harris, J.: Urban and background ozone trend in 1984-1999 at subtropical Hong Kong, South China, Ozone-Sci. Eng., 25, 513-522, 2003.

Chan, C., Li, Y., Tang, J., Leung, Y., Wu, M., Chan, L., Chang, C., and Liu, S.: An analysis on abnormally low ozone in the upper troposphere over subtropical East Asia in spring 2004, Atmos. Environ., 41, 3556-3564, 2007.

Chan, L. Y., Liu, H. Y., Lam, K. S., Wang, T., Oltmans, S. J., and Harris, J. M.: Analysis of the seasonal behavior of tropospheric ozone at Hong Kong, Atmos. Environ., 32, 159-168, 1998.

Considine, D. B., Logan, J. A., and Olsen, M. A.: Evaluation of near-tropopause ozone distributions in the Global Modeling Initiative combined stratosphere/troposphere model with ozonesonde data, Atmos. Chem. Phys., 8, 2365-2385, doi:10.5194/acp-8-2365-2008, 2008.

Cooper, O. R., Parrish, D. D., Stohl, A., Trainer, M., Nedelec, P., Thouret, V., Cammas, J., Oltmans, S. J., Johnson, B. J., Tarasick, D., Leblanc, T., McDermid, I. S., Jaffe, D., Gao, R., Stith, J., Ryerson, T., Aikin, K., Campos, T., Weinheimer, A. J., and Avery, M. A.: Increasing springtime ozone mixing ratios in the free troposphere over western North America, Nature, 463, 344-348, doi:10.1038/nature08708, 2010.

Ding, Y. and Chan, J. C. L.: The East Asian summer monsoon: An overview, Meteorol. Atmos. Phys., 89, 117-142, doi:10.1007/s00703-005-0125-z, 2005.

Ding, A. J., Wang, T., Thouret, V., Cammas, J.-P., and Nédélec, P.: Tropospheric ozone climatology over Beijing: analysis of aircraft data from the MOZAIC program, Atmos. Chem. Phys., 8, 1-13, doi:10.5194/acp-8-1-2008, 2008.

Doughty, D. C., Thompson, A. M., Schoeberl, M. R., Stajner, I., Wargan, K., and Hui, W. C. J.: An intercomparison of tropospheric ozone retrievals derived from two Aura instruments and measurements in western North America in 2006, J. Geophys. Res., 116, D06303, doi:10.1029/2010JD014703, 2011.

Draxler, R. R. and Rolph, G. D.: HYSPLIT (HYbrid Single-Particle Lagrangian Integrated Trajectory) Model access via NOAA ARL READY Website (http://ready.arl.noaa.gov/HYSPLIT.php, last access: 15 January 2013), NOAA Air Resources Laboratory, Silver Spring, MD, 2014.

Dufour, G., Eremenko, M., Orphal, J., and Flaud, J.-M.: IASI observations of seasonal and day-to-day variations of tropospheric ozone over three highly populated areas of China: Beijing, Shanghai, and Hong Kong, Atmos. Chem. Phys., 10, 37873801, doi:10.5194/acp-10-3787-2010, 2010.

Duncan, B. N., Strahan, S. E., Yoshida, Y., Steenrod, S. D., and Livesey, N.: Model study of the cross-tropopause transport of biomass burning pollution, Atmos. Chem. Phys., 7, 3713-3736, doi:10.5194/acp-7-3713-2007, 2007.

Edinger, J. G.: Vertical distribution of photochemical smog in Los Angeles basin, Environ. Sci. Technol., 7, 247-252, doi:10.1021/es60075a004, 1973.

Fiore, A. M., Jacob, D. J., Bey, I., Yantosca, R. M., Field, B. D., Fusco, A. C., and Wilkinson, J. G.: Background ozone over the 
United States: Implications for air quality policy, J. Geophys. Res., 107, 4275, doi:10.1029/2001JD000982, 2002.

Fu, T.-M., Jacob, D. J., Palmer, P. I., Chance, K., Wang, Y. X., Barletta, B., Blake, D. R., Stanton, J. C., and Pilling, M. J.: Space-based formaldehyde measurements as constraints on volatile organic compound emissions in east and south Asia and implications for ozone, J. Geophys. Res., 112, D06312, doi:10.1029/2006JD007853, 2007.

Giglio, L., Descloitres, J., Justice, C. O., and Kaufman, Y. J.: An enhanced contextual fire detection algorithm for MODIS, Remote Sens. Environ., 87, 273-282, doi:10.1016/S00344257(03)00184-6, 2003.

Guenther, A., Karl, T., Harley, P., Wiedinmyer, C., Palmer, P. I., and Geron, C.: Estimates of global terrestrial isoprene emissions using MEGAN (Model of Emissions of Gases and Aerosols from Nature), Atmos. Chem. Phys., 6, 3181-3210, doi:10.5194/acp-63181-2006, 2006.

Hack, J. J.: Parameterization of moist convection in the National Center for Atmospheric Research community climate model (CCM2), J. Geophys. Res., 99, 5551-5568, doi:10.1029/93JD03478, 1994.

Hudman, R. C., Jacob, D. J., Cooper, O. R., Evans, M. J., Heald, C. L., Park, R. J., Fehsenfeld, F., Flocke, F., Holloway, J., Hubler, G., Kita, K., Koike, M., Kondo, Y., Neuman, A., Nowak, J., Oltmans, S., Parrish, D., Roberts, J. M., and Ryerson, T.: Ozone production in transpacific Asian pollution plumes and implications for ozone air quality in California, J. Geophys. Res., 109, D23S10, doi:10.1029/2004JD004974, 2004.

Hudman, R. C., Murray, L. T., Jacob, D. J., Turquety, S., Wu, S., Millet, D. B., Avery, M., Goldstein, A. H., and Holloway, J.: North American influence on tropospheric ozone and the effects of recent emission reductions: Constraints from ICARTT observations, J. Geophys. Res., 114, D07302, doi:10.1029/2008JD010126, 2009.

Jaffe, D., Anderson, T., Covert, D., Kotchenruther, R., Trost, B., Danielson, J., Simpson, W., Berntsen, T., Karlsdottir, S., and Blake, D.: Transport of Asian air pollution to North America, Geophys. Res. Lett., 26, 711-714, doi:10.1029/1999GL900100, 1999.

Lacis, A. A., Wuebbles, D. J., and Logan, J. A.: Radiative forcing of climate by changes in the vertical distribution of ozone, J. Geophys. Res., 95, 9971-9981, doi:10.1029/JD095iD07p09971, 1990.

Lea, D. A.: Vertical ozone distribution in the lower troposphere near an urban pollution complex, J. Appl. Meteorol., 7, 252-267, 1968.

Li, Q., Jacob, D. J., Logan, J. A., Bey, I., Yantosca, R. M., Liu, H. Y., Martin, R. V., Fiore, A. M., Field, B. D., and Duncan, B. N.: A tropospheric ozone maximum over the Middle East, Geophys. Res. Lett., 28, 3235-3238, doi:10.1029/2001GL013134, 2001.

Li, Q., Jacob, D. J., Fairlie, T. D., Liu, H., Martin, R. V., and Yantosca, R. M.: Stratospheric versus pollution influences on ozone at Bermuda: Reconciling past analyses, J. Geophys. Res., 107, 4611, doi:10.1029/2002JD002138, 2002.

Liang, Q., Jaeglé, L., Jaffe, D. A., Weiss-Penzias, P., Heckman, A., and Snow, J. A.: Long-range transport of Asian pollution to the northeast Pacific: Seasonal variations and transport pathways of carbon monoxide, J. Geophys. Res., 109, D23S07, doi:10.1029/2003JD004402, 2004.
Lin, W., Xu, X., Zhang, X., and Tang, J.: Contributions of pollutants from North China Plain to surface ozone at the Shangdianzi GAW Station, Atmos. Chem. Phys., 8, 5889-5898, doi:10.5194/acp-8-5889-2008, 2008.

Lin, M., Holloway, T., Oki, T., Streets, D. G., and Richter, A.: Multiscale model analysis of boundary layer ozone over East Asia, Atmos. Chem. Phys., 9, 3277-3301, doi:10.5194/acp-9-3277-2009, 2009.

Lin, M., Fiore, A. M., Horowitz, L. W., Cooper, O. R., Naik, V., Holloway, J., Johnson, B. J., Middlebrook, A. M., Oltmans, S. J., Pollack, I. B., Ryerson, T. B., Warner, J. X., Wiedinmyer, C., Wilson, J., and Wyman, B.: Transport of Asian ozone pollution into surface air over the western United States in spring, J. Geophys. Res., 117, D00V07, doi:10.1029/2011JD016961, 2012.

Lin, M., Horowitz, L. W., Oltmans, S. J., Fiore, A. M., and Fan, S.: Tropospheric ozone trends at Manna Loa Observatory tied to decadal climate variability, Nat. Geosci., 7, 136-143, doi:10.1038/NGEO2066, 2014.

Liu, H., Chang, W. L., Oltmans, S. J., Chan, L. Y., and Harris, J. M.: On springtime high ozone events in the lower troposphere from southeast Asian biomass burning, Atmos. Environ., 33, 24032410, 1999.

Liu, H., Jacob, D. J., Chan, L. Y., Oltmans, S. J., Bey, I., Yantosca, R. M., Harris, J. M., Duncan, B. N., and Martin, R. V.: Sources of tropospheric ozone along the Asian Pacific Rim: An analysis of ozonesonde observations, J. Geophys. Res., 107, 4573, doi:10.1029/2001JD002005, 2002.

Liu, H., Jacob, D. J., Bey, I., Yantosca, R. M., Duncan, B. N., and Sachse, G. W.: Transport pathways for Asian pollution outflow over the Pacific: Interannual and seasonal variations, J. Geophys. Res., 108, 8786, doi:10.1029/2002JD003102, 2003.

Liu, H., Considine, D. B., Horowitz, L. W., Crawford, J. H., Strahan, S. E., Damon, M., Rodriguez, J. M., Xu, X., Carouge, C. C., and Yantosca, R. M.: Using beryllium-7 to assess cross-tropopause transport in global models, Atmos. Chem. Phys. Discuss., in preparation, 2015.

Liu, J. J., Jones, D. B. A., Worden, J. R., Noone, D., Parrington, M., and Kar, J.: Analysis of the summertime buildup of tropospheric ozone abundances over the Middle East and North Africa as observed by the Tropospheric Emission Spectrometer instrument, J. Geophys. Res., 114, D05304, doi:10.1029/2008JD010993, 2009.

Liu, J., Logan, J. A., Jones, D. B. A., Livesey, N. J., Megretskaia, I., Carouge, C., and Nedelec, P.: Analysis of CO in the tropical troposphere using Aura satellite data and the GEOS-Chem model: insights into transport characteristics of the GEOS meteorological products, Atmos. Chem. Phys., 10, 12207-12232, doi:10.5194/acp-10-12207-2010, 2010.

Marenco, A., Thouret, V., Nédélec, P., Smit, H., Helten, M., Kley, D., Karcher, F., Simon, P., Law, K., and Pyle, J.: Measurement of ozone and water vapor by Airbus in-service aircraft: The MOZAIC airborne program, an overview, J. Geophys. Res., 103, 25631-25642, doi:10.1029/98JD00977, 1998.

Martin, R. V., Jacob, D. J., Logan, J. A., Bey, I., Yantosca, R. M., Staudt, A. C., Li, Q., Fiore, A. M., Duncan, B. N., Liu, H., Ginoux, P., and Thouret, V.: Interpretation of TOMS observations of tropical tropospheric ozone with a global model and in-situ observations, J. Geophys. Res., 107, 4351, doi:10.1029/2001JD001480, 2002. 
McLinden, C. A., Olsen, S. C., Hannegan, B., Wild, O., Prather, M. J., and Sundet, J.: Stratospheric ozone in 3-D models: A simple chemistry and the cross-tropopause flux, J. Geophys. Res., 105, 14653-14665, doi:10.1029/2000JD900124, 2000.

Moody, J. L., Felker, S. R., Wimmers, A. J., Osterman, G., Bowman, K., Thompson, A. M., and Tarasick, D. W.: A multi-sensor upper tropospheric ozone product (MUTOP) based on TES ozone and GOES water vapor: validation with ozonesondes, Atmos. Chem. Phys., 12, 5661-5676, doi:10.5194/acp-12-5661-2012, 2012.

Moorthi, S. and Suarez, M.: Relaxed Arakawa-Schubert: A parameterization of moist convection for general circulation models, Mon. Weather Rev., 120, 978-1002, 1992.

Nassar, R., Logan, J. A., Megretskaia, I. A., Murray, L. T., Zhang, L., and Jones D. B. A.: Analysis of tropical tropospheric ozone, carbon monoxide, and water vapor during the 2006 El Niño using TES observations and the GEOS-Chem model, J. Geophys. Res., 114, D17304, doi:10.1029/2009JD011760, 2009.

Olivier, J. G. J. and Berdowski, J. J. M.: Global emissions source and sinks, in: The Climate System, edited by: Berdowski, J., Guicherit, R., and Heji, B. J., p. 33-78, A. A. Balkema, Lisse, Netherlands, 2001.

Park, R. J., Jacob, D. J., Field, B. D., Yantosca, R. M., and Chin, M.: Natural and transboundary pollution influences on sulfate-nitrate-ammonium aerosols in the United States: Implications for policy, J. Geophys. Res., 109, D15204, doi:10.1029/2003JD004473, 2004.

Pickering, K. E., Wang, Y., Tao, W.-K., Price, C., and Müller, J.-F.: Vertical distributions of lightning $\mathrm{NO}_{x}$ for use in regional and global chemical transport models, J. Geophys. Res., 103, 3120331216, doi:10.1029/98JD02651, 1998.

Price, C. and Rind, D.: A simple lightning parameterization for calculating global lightning distributions, J. Geophys. Res., 97, 9919-9933, doi:10.1029/92JD00719, 1992.

Richter, A., Burrows, J. P., Nüß, H., Granier, C., and Niemeier, U.: Increase in tropospheric nitrogen dioxide over China observed from space, Nature, 437, 129-132, doi:10.1038/nature04092, 2005.

Rienecker, M. M., Suarez, M. J., Todling, R., Bacmeister, J., Takacs, L., Liu, H.-C., Gu, W., Sienkiewicz, M., Koster, R. D., Gelaro, R., Stajner, I., and Nielsen, J. E.: The GEOS-5 Data Assimilation System - Documentation of Versions 5.0.1, 5.1.0, and 5.2.0. Tech. Rep. NASA-TM-104606, Technical Report Series on Global Modeling and Data Assimilation, Vol. 27, 101 pp., Greenbelt, Maryland, USA, 2008.

Rolph, G. D.: Real-time Environmental Applications and Display sYstem (READY) Website (http://ready.arl.noaa.gov, last access: 15 January 2013), NOAA Air Resources Laboratory, Silver Spring, MD, 2014.

Sauvage, B., Martin, R. V., van Donkelaar, A., Liu, X., Chance, K., Jaeglé, L., Palmer, P. I., Wu, S., and Fu, T.-M.: Remote sensed and in situ constraints on processes affecting tropical tropospheric ozone, Atmos. Chem. Phys., 7, 815-838, doi:10.5194/acp-7-815-2007, 2007.

Strahan, S. E., Duncan, B. N., and Hoor, P.: Observationally derived transport diagnostics for the lowermost stratosphere and their application to the GMI chemistry and transport model, Atmos. Chem. Phys., 7, 2435-2445, doi:10.5194/acp-7-2435-2007, 2007.
Streets, D. G., Bond, T., Carmichael, G., Fernandes, S., Fu, Q., He, D., Klimont, Z., Nelson, S., Tsai, N., and Wang, M. Q.: An inventory of gaseous and primary aerosol emissions in Asia in the year 2000, J. Geophys. Res., 108, 8809, doi:10.1029/2002JD003093, D21, 2003.

Streets, D. G., Zhang, Q., Wang, L., He, K., Hao, J., Wu, Y., Tang, Y., and Carmichael, G. R.: Revisiting China's CO emissions after the Transport and Chemical Evolution over the Pacific (TRACE-P) mission: Synthesis of inventories, atmospheric modeling, and observations, J. Geophys. Res., 111, D14306, doi:10.1029/2006JD007118, 2006.

Streets, D. G., Fu, J. S., Jang, C. J., Hao, J., He, K., Tang, X., Zhang, Y., Wang, Z., Li, Z., and Zhang, Q.: Air quality during the 2008 Beijing Olympic games, Atmos. Environ., 41, 480-492, 2007.

Sudo, K. and Akimoto, H.: Global source attribution of tropospheric ozone: Long-range transport from various source regions, J. Geophys. Res., 112, D12302, doi:10.1029/2006JD007992, 2007.

Thompson, A. M.: The oxidizing capacity of the earth's atmosphere: Probable past and future changes, Science, 256, 1157$1165,1992$.

Thouret, V., Marenco, A., Nédélec, P., and Grouhel, C.: Ozone climatologies at $9-12 \mathrm{~km}$ altitude as seen by the MOZAIC airborne program between September 1994 and August 1996, J. Geophys. Res., 103, 25653-25679, doi:10.1029/98JD01807, 1998.

Thouret, V., Cammas, J.-P., Sauvage, B., Athier, G., Zbinden, R., Nédélec, P., Simon, P., and Karcher, F.: Tropopause referenced ozone climatology and inter-annual variability (1994-2003) from the MOZAIC programme, Atmos. Chem. Phys., 6, 1033-1051, doi:10.5194/acp-6-1033-2006, 2006.

van der Werf, G. R., Randerson, J. T., Giglio, L., Collatz, G. J., Kasibhatla, P. S., and Arellano Jr., A. F.: Interannual variability in global biomass burning emissions from 1997 to 2004, Atmos. Chem. Phys., 6, 3423-3441, doi:10.5194/acp-6-3423-2006, 2006.

van Donkelaar, A., Martin, R. V., Leaitch, W. R., Macdonald, A. M., Walker, T. W., Streets, D. G., Zhang, Q., Dunlea, E. J., Jimenez, J. L., Dibb, J. E., Huey, L. G., Weber, R., and Andreae, M. O.: Analysis of aircraft and satellite measurements from the Intercontinental Chemical Transport Experiment (INTEX-B) to quantify long-range transport of East Asian sulfur to Canada, Atmos. Chem. Phys., 8, 2999-3014, doi:10.5194/acp-8-2999-2008, 2008.

Wang, T., Ding, A., Gao, J., and Wu, W. S.: Strong ozone production in urban plumes from Beijing, China, Geophys. Res. Lett., 33, L21806, doi:10.1029/2006GL027689, 2006.

Wang, T., Wei, X. L., Ding, A. J., Poon, C. N., Lam, K. S., Li, Y. S., Chan, L. Y., and Anson, M.: Increasing surface ozone concentrations in the background atmosphere of Southern China, 19942007, Atmos. Chem. Phys., 9, 6217-6227, doi:10.5194/acp-96217-2009, 2009.

Wang, Y., Jacob, D. J., and Logan, J. A.: Global simulation of tropospheric $\mathrm{O}_{3}-\mathrm{NO}_{x}$-hydrocarbon chemistry: 3. Origin of tropospheric ozone and effects of nonmethane hydrocarbons, J. Geophys. Res., 103, 10757-10767, doi:10.1029/98JD00156, 1998.

Wang, Y., McElroy, M. B., Munger, J. W., Hao, J., Ma, H., Nielsen, C. P., and Chen, Y.: Variations of $\mathrm{O}_{3}$ and $\mathrm{CO}$ in summertime at a rural site near Beijing, Atmos. Chem. Phys., 8, 6355-6363, doi:10.5194/acp-8-6355-2008, 2008. 
Wang, Y., Konopka, P., Liu, Y., Chen, H., Müller, R., Plöger, F., Riese, M., Cai, Z., and Lü, D.: Tropospheric ozone trend over Beijing from 2002-2010: ozonesonde measurements and modeling analysis, Atmos. Chem. Phys., 12, 8389-8399, doi:10.5194/acp-12-8389-2012, 2012.

Yevich, R. and Logan, J. A.: An assessment of biofuel use and burning of agricultural waste in the developing world, Global Biogeochem. Cycles, 17, 1095, doi:10.1029/2002GB001952, 2003.

Zhang, G. J. and McFarlane, N. A.: Sensitivity of climate simulations to the parameterization of cumulus convection in the Canadian Climate Centre general circulation model, AtmosphereOcean, 33, 407-446, 1995.

Zhang, Q., Zhao, C., Tie, X., Wei, Q., Huang, M., Li, G., Ying, Z., and Li, C.: Characterizations of aerosols over the Beijing region: A case study of aircraft measurements, Atmos. Environ., 40, 4513-4527, doi:10.1016/j.atmosenv.2006.04.032, 2006.
Zhang, L., Jacob, D. J., Boersma, K. F., Jaffe, D. A., Olson, J. R., Bowman, K. W., Worden, J. R., Thompson, A. M., Avery, M. A., Cohen, R. C., Dibb, J. E., Flock, F. M., Fuelberg, H. E., Huey, L. G., McMillan, W. W., Singh, H. B., and Weinheimer, A. J.: Transpacific transport of ozone pollution and the effect of recent Asian emission increases on air quality in North America: an integrated analysis using satellite, aircraft, ozonesonde, and surface observations, Atmos. Chem. Phys., 8, 6117-6136, doi:10.5194/acp-8-6117-2008, 2008.

Zhang, L., Li, Q. B., Jin, J., Liu, H., Livesey, N., Jiang, J. H., Mao, Y., Chen, D., Luo, M., and Chen, Y.: Impacts of 2006 Indonesian fires and dynamics on tropical upper tropospheric carbon monoxide and ozone, Atmos. Chem. Phys., 11, 10929-10946, doi:10.5194/acp-11-10929-2011, 2011.

Zhang, Y., Liu, H., Crawford, J. H., Considine, D. B., Chan, C., Oltmans, S. J., and Thouret, V.: Distribution, variability and sources of tropospheric ozone over south China in spring: Intensive ozonesonde measurements at five locations and modeling analysis, J. Geophys. Res., 117, D12304, doi:10.1029/2012JD017498, 2012. 